\title{
Cretaceous syn-sedimentary faulting in the Wildhorn Nappe (SW Switzerland)
}

\section{Journal Article}

\section{Author(s):}

Cardello, Giovanni L.; Mancktelow, Neil S.

Publication date:

2014-12

Permanent link:

https://doi.org/10.3929/ethz-b-000096022

\section{Rights / license:}

In Copyright - Non-Commercial Use Permitted

\section{Originally published in:}

Swiss Journal of Geosciences 107(2-3), https://doi.org/10.1007/s00015-014-0166-8 


\title{
Cretaceous syn-sedimentary faulting in the Wildhorn Nappe (SW Switzerland)
}

\author{
G. L. Cardello $•$ Neil S. Mancktelow
}

Received: 25 August 2013/Accepted: 2 September 2014/Published online: 7 October 2014

(C) Swiss Geological Society 2014

\begin{abstract}
During Cretaceous time, the area of the future Helvetic nappes (Central Alps, south-western Switzerland) was part of a large ramp-type carbonate depositional system on the European margin, in which the area of the Wildhorn Nappe was transitional to the more distal and relatively deeper Ultrahelvetic basin. The Wildhorn Nappe includes an Upper Cretaceous succession bearing clear evidence for syn-sedimentary normal faulting, such as synsedimentary geometries related to well oriented NE-striking faults, sedimentary dykes, lateral variations in the thickness and facies of formations, anomalous and discordant contacts corresponding to palaeo-escarpments, and slump folds. Four stages of syn-sedimentary fault activity have been recognized. (1) Post-Cenomanian disruption and exhumation of the Schrattenkalk platform related to distributed normal faulting, which contributed to the initiation of karst erosion on topographic highs and sedimentation in topographic lows. (2) Turonian-Santonian marine transgression accompanied by localized normal faulting, creating growth-fault structures, differential subsidence and slope instability. A transition from distributed to more localized faulting is observed, related to a final stage in the evolution of the Cretaceous extensional process. (3) Early Maastrichtian faulting. The facies and thickness of
\end{abstract}

Editorial handling: A. G. Milnes.

G. L. Cardello ( $\bowtie)$

ISTO, Institut des Sciences de la Terre d'Orléans,

Université d'Orléans, 1A Rue de la Ferollerie,

45071 Orléans Cedex 2, France

e-mail: luca.cardello@univ-orleans.fr

G. L. Cardello · N. S. Mancktelow

Department of Earth Sciences, ETH Zürich, 8092 Zürich,

Switzerland subsequent sediments reflect a passive adaption to the preexisting topography of the sea floor, established during the earlier tectonic movements. (4) Post-Maastrichtian northdirected tilt and erosion. In the Wildhorn Nappe, palaeofault activity most probably ended in the Early Maastrichtian rather than continuing into the Eocene. Until now, the regional importance and magnitude of Late Cretaceous extension has not been recognized in the Helvetic domain. This widespread event may be related to post-breakup extensional tectonics along the European margin or, alternatively but less likely, to lateral gravitational collapse of the margin.

Keywords Central Alps - Helvetic nappes ·

Cretaceous extensional faults - Post-breakup tectonics .

Carbonate depositional systems $\cdot$ Multiple fault systems

\section{Introduction}

This paper documents in detail Cretaceous syn-sedimentary faults from the south-western Helvetic Alps, with implications for the palaeogeographic and structural setting of the European margin at that time. In particular, we consider the pre-orogenic tectonic and stratigraphic setting of the Wildhorn Nappe, the southernmost of the Helvetic nappes according to palaeogeographic reconstructions (e.g. Trümpy 1960; Ramsay et al. 1981; Ramsay 1989; Pfiffner 2011). The field characteristics and arrangement of the different fault sets is established and the structural relevance of the Cretaceous syn-sedimentary faults at the regional and plate-tectonic scale discussed. The field area is crossed by a large number of faults of different orientation, length, kinematics, geometry and age. As noted by Gasser and Mancktelow (2010), these can be subdivided 


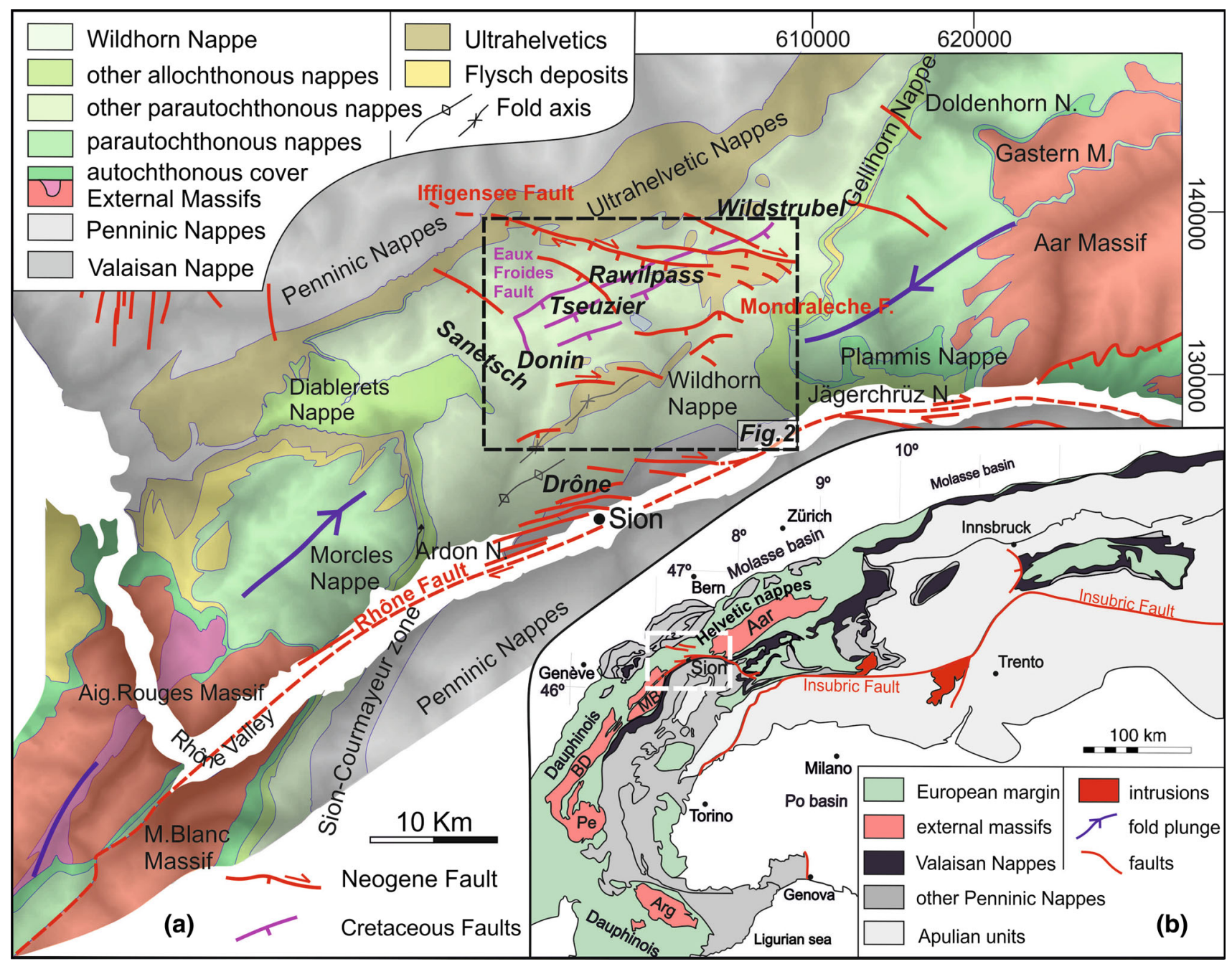

Fig. 1 a Simplified tectonic map of south-western Switzerland showing the location of the study area (Fig. 2; profiles $\mathrm{AB}$ and $\mathrm{CD}$, Fig. 3). Thick blue lines indicate the axial plunge of Helvetic nappes on either side of the Rawil depression (modified from Tectonic Map

into four sets: (1) NE-SW- and (2) NW-SE-striking normal faults and joints, and (3) ENE-WSW- and (4) WNWESE-striking normal plus oblique-slip normal faults. As we show here, most of the NE-SW-striking normal faults are related to Cretaceous syn-sedimentary faulting. These synsedimentary faults are not only important for controlling the geometry of the passive margin and the distribution of sedimentary facies: they may also have an influence on tectonic structures during collision and exhumation. The study area (Fig. 1) is still undergoing convergence and is currently one of the most seismically active parts of the Alps (Pavoni 1980; Maurer et al. 1997; Kastrup et al. 2004; Ustaszweski and Piffner 2008). Establishing whether a particular fault is a dormant palaeo-fault, a reactivated palaeo-fault or a young tectonic fault without an earlier syn-sedimentary precursor is therefore also of interest for assessing seismic risk in the area. of Switzerland). Tectonic overview map of the Alpine orogenic belt in Europe, showing the area covered by a (modified after Bigi and Carozzo 1992)

In the area of the Wildhorn Nappe considered here (Rawil region of south-western Switzerland), pre-orogenic faults were already recognized in the pioneering work of Günzler-Seiffert (1932, 1934, 1942, 1952). He described "persistent" syn-sedimentary normal faults that were active from Middle to Late Jurassic, with accumulated displacements of up to $60 \mathrm{~m}$. Further east, in the central and eastern region of the Helvetic nappes, Strasser (1982) inferred that syn-sedimentary normal faulting had influenced sedimentation of the Lower Cretaceous (Valanginian) Betlis Limestone. Funk (in Trümpy 1980) also interpreted abrupt thickness variations in the Helvetic siliceous limestones (Kieselkalk) in the eastern region of the Helvetic nappes to be related to syn-sedimentary normal faulting during the Hauterivian $(\sim 130 \mathrm{Ma})$. In the Wildhorn Nappe area investigated here, Günzler-Seiffert (1952) also recognized that gaps and changes in thickness 


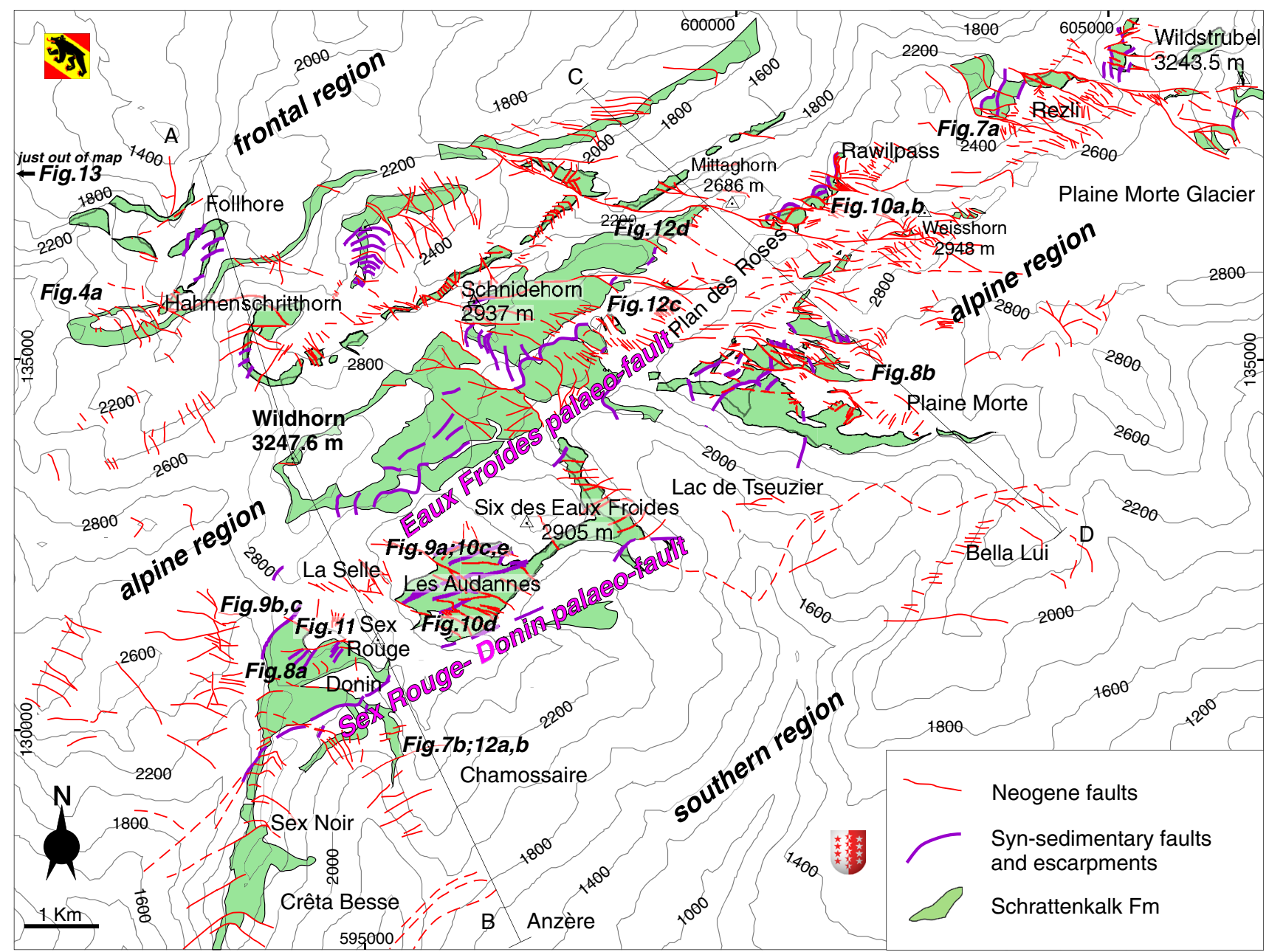

Fig. 2 Topographic map of the study area (for location see Fig. 1). Selected geological data are plotted (see legend), as well as traces of the profiles $\mathrm{AB}$ and $\mathrm{CD}$ (on Fig. 3) and the location of outcrops and the viewpoints of panoramic photographs with figure numbers. The

in the Upper Cretaceous sedimentary succession were directly related to syn-sedimentary faulting. Similarly, Lugeon (1914-1918) and Föllmi and Gainon (2008) described syn-sedimentary faulting active during the Late Cretaceous (Santonian) in the Col de la Plaine Morte area.

However, as was noted by Trümpy (1960, p. 882), "the tensional effect of the fault movements is clear enough for Jurassic time, but the later and weaker Cretaceous and Eocene movements are not so easy to interpret". Up to now, the younger (Late Cretaceous) syn-sedimentary faults in the Wildhorn Nappe have not been documented extensively and their progressive development and origin have not been addressed in any real detail. In order to establish their significance, it was first necessary to map out the distribution of faults, to estimate the displacements on individual faults, and to determine their influence on the stratigraphic pattern. In this paper, we present stratigraphic outcrops of the Schrattenkalk Formation are often associated with syn-sedimentary structures. For descriptive purposes, the study area has been subdivided into regions: "frontal region", "alpine region" and "southern region" (see text)

and structural data related to the syn-sedimentary faulting that affected the Wildhorn Nappe, providing new information on the continued evolution of the European "passive" margin during Cretaceous to Tertiary times.

\section{Methods}

This work is based on field mapping (at 1:10,000 scale) of an area of about $200 \mathrm{~km}^{2}$, from the Sanetsch pass to the Wildstrubel (Figs. 1, 2). The stratigraphic subdivision used here is based on the table published by the Swiss Commission for Stratigraphy (http://www.stratigraphie.ch). All the geological formation names are used here informally because, although they correspond to litho-stratigraphic units defined by clear boundaries and typical characteristics, the mappable units may be diachronous from place to 
place and a detailed biostratigraphic study was not part of the current work. In this study, we use the term 'internal' when a lithofacies is in a position relatively closer to the deep basinal domain and 'external' when a facies is relatively closer to the shore line. All outcrop locations are referenced in Swiss grid coordinates (e.g. 601250/137135; Easting/Northing).

The thickness of formations has been measured from geological sections as close to perpendicular to the bedding planes as possible, in order to accurately determine the current thickness. The analysis of panorama photographs also helped in extrapolating the general trend of sedimentary facies and formational thickness information. Faciesdependent and burial-related compaction was not explicitly considered in the current study. However, although it will have modified currently measured bed thicknesses, it is not considered to have had a major influence on the original first-order stratigraphic relationships. This is particularly true for platform limestones such as the Schrattenkalk Formation, which are key marker levels involved in Late Cretaceous faulting but are generally less affected by pressure-solution and compaction. Detailed mapping of the stratigraphic relationships along syn-sedimentary faults and escarpments has enabled us to date the movements on the studied faults relative to the stratigraphy. Note that in this paper the terms Upper/Lower are used for chronostratigraphic (time-rock) units and Early/Late for geochronological (time) units following, for example, Haile (1987), Owen (2009) and Zalasiewicz et al. (2013).

\section{Geological background}

The Helvetic nappe system forms a fold-and-thrust belt on the northern flank of the Central Alps of Switzerland (e.g. Ramsay et al. 1981; Pfiffner 2011). To the west, equivalent tectonic units continue into the Western Alps of France, where they are referred to as the Dauphinois zone, becoming a more "parautochthonous" fold-and-thrust belt (e.g. Froitzheim et al. 1996). To the east of Switzerland, they continue as a thin zone exposed below the Austroalpine nappes in Austria (e.g. Pfiffner 2011).

On a broad scale, the nappe stack in the study area is composed of three main tectonic units reflecting the original palaeogeographic domains (generally referred to as the Helvetic, Ultrahelvetic and Penninic domains, going oceanward from the European foreland). Each unit shows internal stratigraphic heterogeneity as well as minor thrusts and folds of smaller scale. The nappes were emplaced in the time period from ca. 27 to $15 \mathrm{Ma}$ (Kirschner et al. 2003) and weakly metamorphosed under anchizone to lower greenschist facies (Bussy and Epard 1984; Burkhard and Kerrich 1988). The metamorphic grade generally increases towards the south. The nappe pile was subsequently affected by dominantly dextral transtensional faults developed or reactivated during the Neogene (Huggenberger and Aebli 1989; Burkhard 1988; Pfiffner 1993; Gasser and Mancktelow 2010; Cardello and Tesei 2013). The study area lies within the Rawil depression (Heim 1920), which preserves the highest nappes between two more deeply exhumed domal culminations, forming the Mont Blanc/Aiguilles Rouges and Aar/Gastern "External Crystalline Massifs" (Fig. 1).

Several Helvetic nappes have been distinguished in the region considered here: the lower and more external unit is the Morcles Nappe, successively overlain by the higher and more internal Diablerets and Wildhorn Nappes (Heim 1920; Pfiffner 1993). Escher et al. (1993) have further subdivided the Wildhorn Nappe into the lower Mont Gond Nappe and the upper Sublage Nappe. On the north-eastern side of the Rawil depression, the Helvetic nappes have been referred to as the Doldernhorn, Gellihorn and Wildhorn Nappes (Heim 1920). An overview of the Helvetic nappes in this region is given in Burkhard (1988). The stratigraphic successions of the Morcles and Diablerets Nappes are mainly composed of shallow water deposits, with marked stratigraphic gaps (e.g. the Upper Cretaceous to Lower Tertiary sediments are missing). These units were topographically higher and periodically exposed and eroded due to tectonism or sea-level changes. Thicker and more continuous successions occur in the Wildhorn Nappe, which was palaeogeographically more to the south. Here the Upper Cretaceous deposits are preserved and characterized by unconformities and anomalous stratigraphic contacts, which provide information about the time and style of syn-sedimentary faulting.

The Wildhorn Nappe, at the border between the cantons of Valais and Bern in south-western Switzerland, can be subdivided into three regions characterized by a similar structural style (Figs. 2, 3). From north to south, we will refer to these here as: (1) the "frontal region", defined by tight folds with a wavelength of ca. $600 \mathrm{~m}$ (Fig. 4), with thrusts cutting out their overturned limbs; (2) the higher "alpine region", which best preserves the pre-Alpine structures related to syn-sedimentary extension; and (3) the "southern region", which is characterized by the repetition of tight to isoclinal folds that are subsequently multiply refolded.

This work focuses on the "alpine region", which is mainly represented by gently folded Jurassic to Tertiary units on the upright limb of the Wildhorn Nappe. In particular, the calcareous plateaux of the Donin, Les Audannes, Plan des Roses, Plaine Morte, Rawil, and RezliWildstrubel contain excellent examples of Cretaceous synsedimentary structures (Figs. 2, 3). 


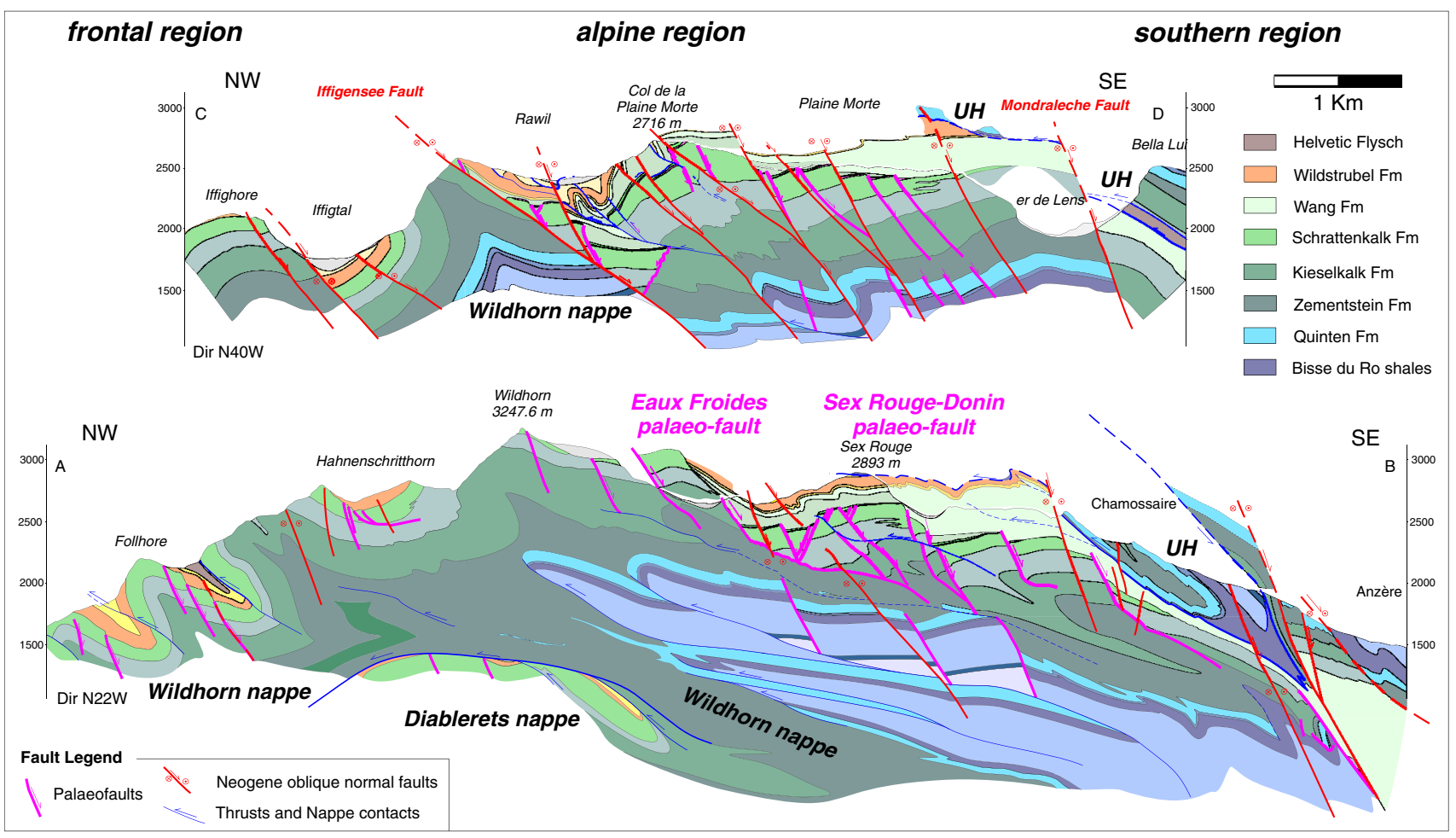

Fig. 3 Synthetic geological profiles, the trace of which are indicated on the map of Fig. 2. The deep structure of profile AB is based on a reinterpretation of the map and profiles of Badoux et al. (1959) and our own field data. For colour scheme, refer to the stratigraphic column (Fig. 5). Blue lines thrusts, red lines late Alpine (transtensive to normal) faults, violet lines normal palaeo-faults
During Alpine orogenesis, the Triassic-Tertiary succession was folded disharmonically, producing folds of different wavelength and magnitude, in some cases directly associated with thrusts. The "frontal region" is detached from its Jurassic succession, which remained behind (e.g. the Mont Gond structure and the Sublage and Sérac anticlines; Escher et al. 1993). As a consequence, the oldest part of the succession outcrops in the south whereas the "alpine region" is essentially dominated by Jurassic to Tertiary units. The major tectonic discontinuity within the Wildhorn Nappe occurs in the Lower Cretaceous Zementstein Formation, decoupling the Cretaceous-Tertiary units from the Jurassic succession. This decollement is important for accommodating disharmonic folding even though it only has a modest thrust displacement on the order of a few $100 \mathrm{~m}$. Other minor decollements occur in the Lower and Upper Jurassic shales and locally also in the Upper Cretaceous-Tertiary succession.

The first Alpine thrusting in the area is represented by the Ultrahelvetic Basal Thrust (UHBT), which juxtaposed the Ultrahelvetic nappes on top of the Wildhorn Nappe. In a second stage, this thrust was then folded together with the underlying rocks during development of the Wildhorn Nappe. In the "alpine" and "southern regions", it is possible to establish the occurrence of at least three folding stages that post-date the UHBT: (1) D1 folds with axes trending NESW; (2) D2 asymmetric folding associated with a spaced crenulation cleavage and related to top-to-NW displacement, with fold axes sub-parallel to the D1 folds; (3) D3 box-folding with fold axes trending $\mathrm{N}-\mathrm{S}$ and with generally steep axial planes, which is mainly observed in the shaly lithologies. Traces of a further D4 phase also occur in the "southern region", with fold axes trending NE-SW and axial planes dipping steeply to the NW. The best example of a tight to isoclinal D1 fold is the Prabé synform (Badoux 1946) at the Chamossaire (profile A-B in Fig. 3), which refolds the older UHBT. The basal thrust of the Wildhorn Nappe is most likely related to the first phase of deformation. D2 folds are generally quite open, always upright and with wavelengths of a few tens of metres. Both D3 and D4 are associated with veining, with veins sometimes parallel to the respective axial planes.

The whole edifice was later cross-cut by low to high angle faults with generally oblique (dextral plus normal) displacement, which are closely associated with more diffuse veining and pressure-solution. Most of the late Alpine faults outcrop between the Wildhorn and Wildstrubel mountains in the Rawil axial depression. Accumulated displacements range up to ca. $1 \mathrm{~km}$ on the major structures, such as the Rezli Fault (Gasser and Mancktelow 2010), the Gletcherhorn Fault, the Iffigensee Fault (Burkhard 1988; Huggenberger and Aebli 1989), and the Mondraleche Fault (Lugeon 1914-1918), but are more typically on the order of a few tens of metres. 

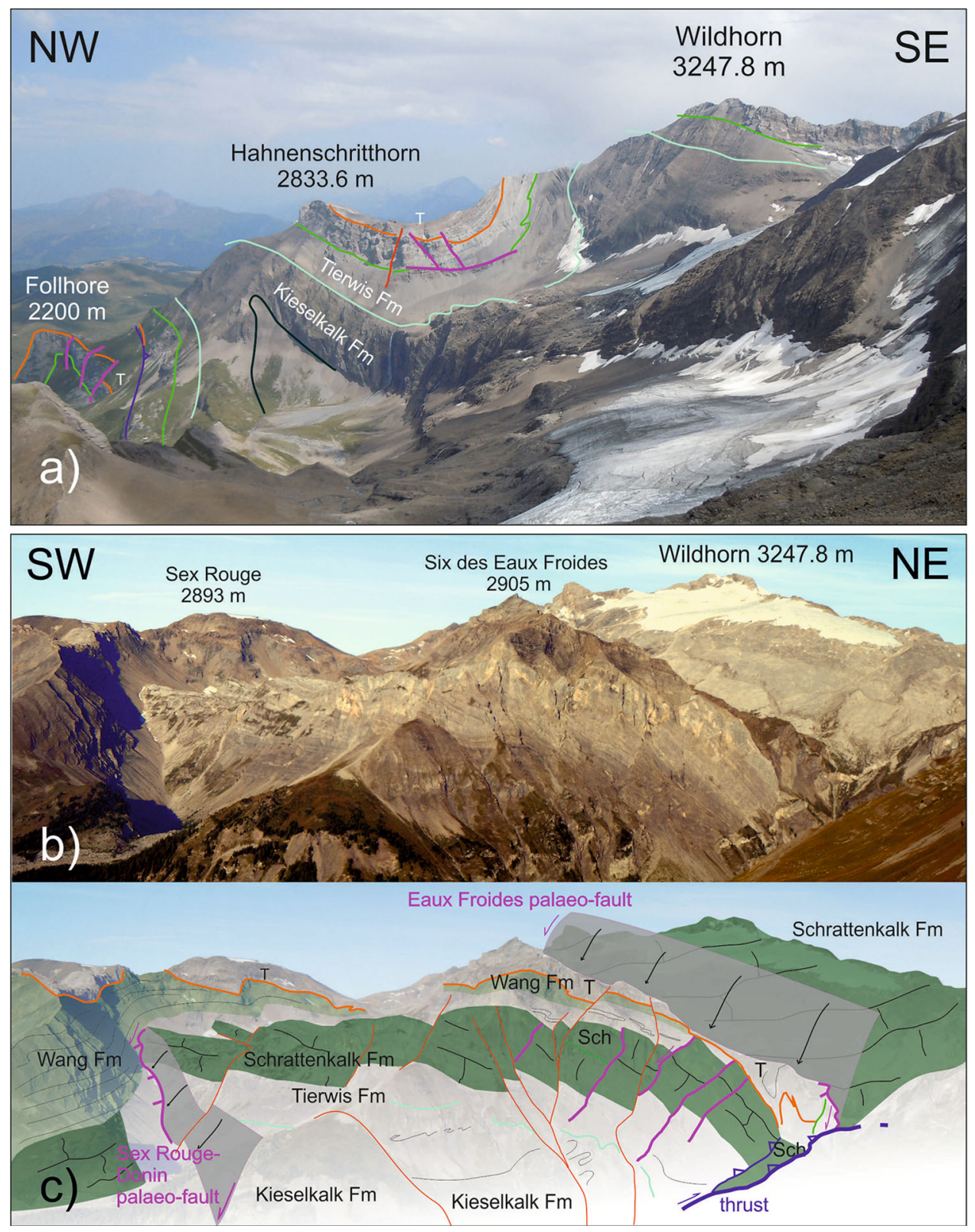

Fig. 4 Wildhorn area ("frontal region" and northern part of the "alpine region") showing an example of the folding style (cf. Fig. 3, profile $\mathrm{AB}$ ). Red lines Neogene faults, violet palaeo-faults, blue thrusts, other coloured lines formational limits. b, c Panoramic view of the southern flank of the Wildhorn ("southern region" and "alpine region"). The panoramic photograph of a shows the north-western end of profile $\mathrm{AB}$, and that of $\mathbf{b}, \mathbf{c}$ the south-western end of profile $\mathrm{AB}$ (viewed from opposite direction). The thickness changes across the palaeo-faults (violet) in the Wang Formation seal the palaeotopography created by the Cretaceous syn-sedimentary faulting. Neogene faults (red lines) cross-cut the whole structure

More stratigraphic details are provided in Cardello (2013) and the references therein.

\subsection{Cretaceous stratigraphy}

Deposition of the Schrattenkalk Formation (Late Barremian-Early Aptian) immediately preceded synsedimentary faulting and forms a clear stratigraphic marker 
Fig. 5 Stratigraphic column of the Wildhorn Nappe (compiled from the following main sources: Badoux et al. 1959, 1962; Pfiffner 2009 and http:// www.stratigraphie.ch). In blue, major unconformities. Thick black lines main hardground crusts, red lines with arrows thrusts

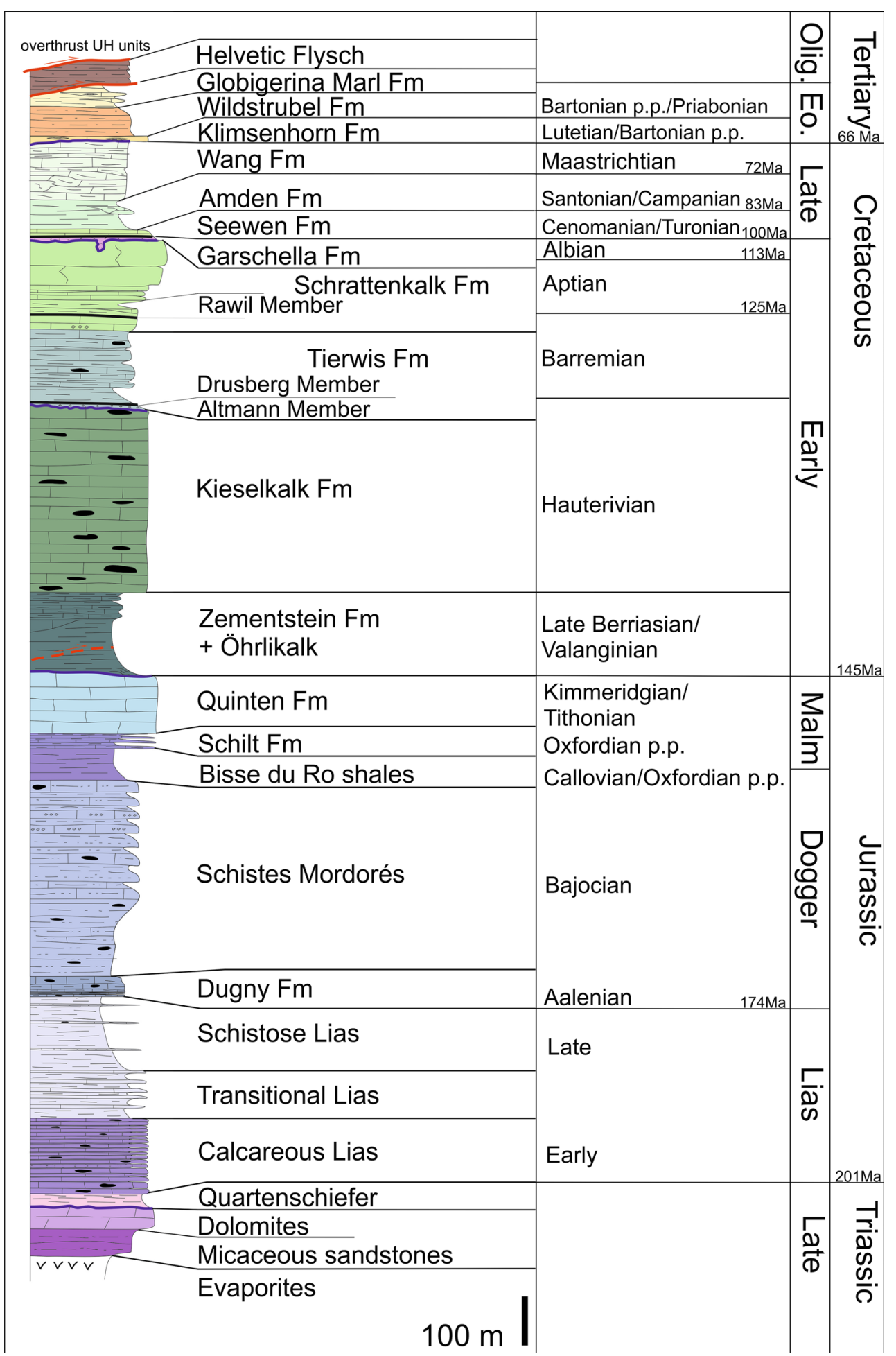

in the field, being represented by whitish grainstones and packstones related to the development of the Urogonian carbonate platform. This platform prograded during the late Early Cretaceous into more distal areas of the European margin (Föllmi et al. 2007). This progression was interrupted by an increase of detrital input in the Early Aptian, represented by marls and fine grained calcarenites of the Rawil Member (Föllmi et al. 2007). According to Föllmi and Gainon (2008), the Rawil Member divides the Schrattenkalk Formation into a lower part rich in crinoids and fragments of rudists and an upper part characterized by rudists and (rare) coral patch-reefs. As shown in Fig. 6, in 


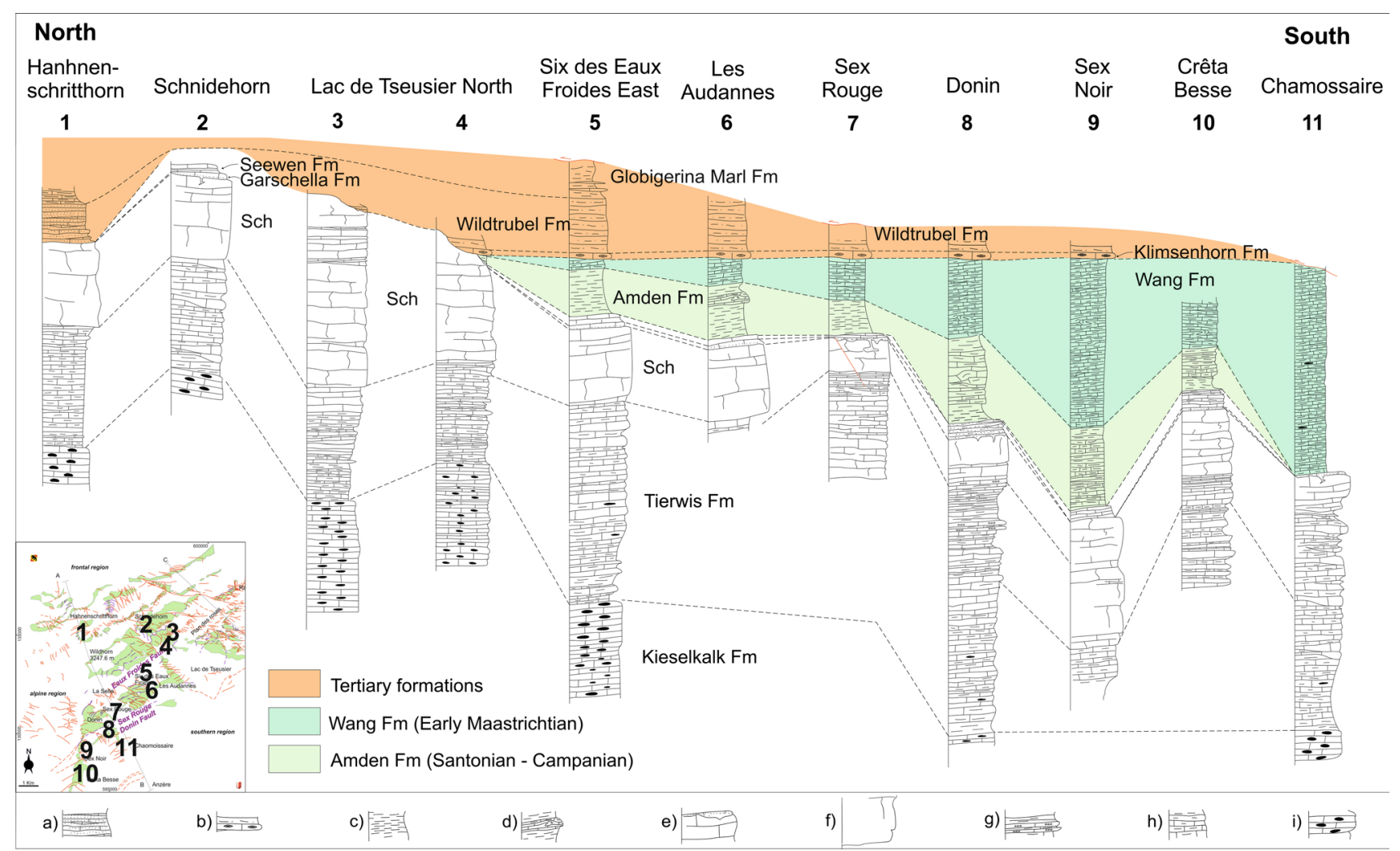

Fig. 6 Comparison of stratigraphic sections. The Wang Formation is thicker towards the south (localities 8-11) and the Amden Formation has a lenticular shape (between localities 4 and 11). Bottom left inset shows the named section locations on Fig. 2. Bottom facies legend. a Alternating calcarenites and sandstones, b Nummulitic calcarenites and siltstones, $\mathbf{c}$ shales, $\mathbf{d}$ slump limestones within shales, e karstified well-bedded platform limestones, f massive platform limestones, g alternating re-sedimented calcarenites rich in crinoids and marls, h marls, $\mathbf{i}$ cherty limestones

to ca. 20-30 m (e.g. Plaine Morte). In reduced sections, phosphate (locally forming more continuous phosphatic horizons) and dark calcareous pebbles are preserved in pockets on top of a Schrattenkalk rudist-rich layer. The top of the Garschella Formation is usually characterized by carbonate-rich greywackes and crinoidal impure limestones. However, in the Rawil area (601250/137135) and north of Wildstrubel (605350/139334), a thin succession (ca. $2 \mathrm{~m}$ thick) of dark shales and marls topped by a thin layer of conglomerate rich in phosphatic nodules and pebbles of reworked pelagic limestones represents the uppermost layers of the Garschella Formation (see Sect. 5).

The overlying Upper Cretaceous succession is characterized by a sequence of basinal limestones and marls showing lateral variation of facies and thickness. The Seewen Formation (Late Turonian-Campanian; Föllmi and Gainon 2008) is a well-bedded succession, 1-30 m thick, of grey and pinkish pelagic limestone rich in microforaminifera. At the Rawilpass, as well as the Plaine Morte (602406/134022), the base of the formation is represented by a grey micritic layer with abundant nodules of phosphatized limestone clasts and pyrite on top of the first layer 
covering the Garschella Formation, suggesting reduced sedimentation rates. Close to escarpments (see Sect. 5.6), pebbly-mudstones and breccias occur. At Les Audannes,
Plan des Roses and on the northern slope of Wildstrubel, Seewen Formation pelagic limestones of Turonian age directly cover the escarpments.
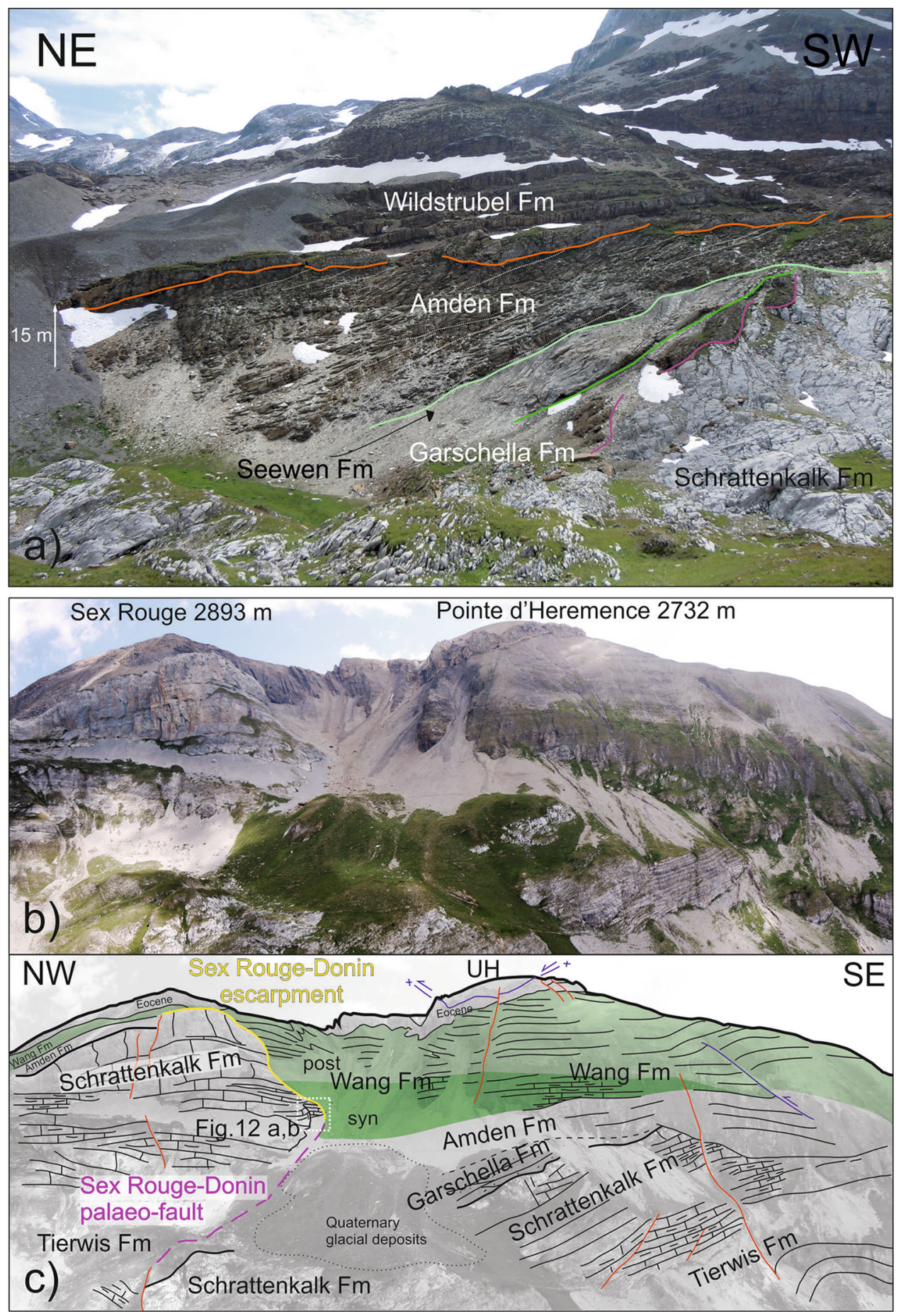

Fig. 7 a Rezli area (603719/138414); for location, see Fig. 2: tilted Schrattenkalk and Garschella Formations are progressively onlapped during sedimentation of the Amden Formation. Base and top of Amden Formation are unconformable, with the Tertiary succession transgressive onto the Cretaceous sequence. b, $\mathbf{c}$ The southern part of the Sex Rouge area (for location, see Fig. 2): growth fault-related structure during sedimentation of the Amden Formation and the lower part of the Wang Formation (Early Maastrichtian). The Eocene deposits lie unconformably on the Wang Formation. Yellow line palaeo-escarpment. The Wang Formation passively recovers the relief by increasing sedimentation rate on the hanging wall of the no-longer active faults 
The Amden Formation (Santonian-Campanian) consists of light grey and beige marls and marly shales intercalated with very fine grained calcarenites (Fig. 10e). The formational thickness ranges from 50 to $120 \mathrm{~m}$, depending on its palaeogeographic position. Close to escarpments, the formation shows growth fault-related structures (Sect. 5.4). The basal boundary is discrete and the upper limit is also sharp (Figs. 7, 8) and marked by an angular unconformity against the Lower Maastrichtian marls of the Wang Formation. At La Selle (594411/131238), lenses of grey to pinkish slumped pelagic limestones rich in bioclasts are intercalated in the Amden Formation. A similar situation was observed at the Plaine Morte, where Villars (1989) dated the slumped beds as Turonian in age, establishing that they therefore represent re-sedimented limestones of the Seewen Formation within the Amden Formation.

The Wang Formation (Late Campanian-Maastrichtian) is represented by dark grey marls and fine grained calcarenites that crop out only in the southern part of the "alpine region". Moving to the south, the Wang Formation progressively covers older formations and the thickness increases from ca. $50 \mathrm{~m}$ at Sex Rouge to ca. 300-350 $\mathrm{m}$ at Les Andines (Figs. 2, 4b). With increasing thickness, internal unconformities and calcturbidites become more abundant in the Wang Formation. In the Chamossaire area, on the western side of Wildstrubel, and in the eastern Plaine Morte (602406/ 134022), dark marls alternating at the base with crinoidal calcarenites of the Wang Formation lie unconformably on top of the Schrattenkalk and Tierwis Formations (Figs. 6, 7b, c). This unconformity is punctuated by silica- and phosphate-rich crusts and nodules. Locally, close to small scale escarpments, the unconformity is also marked by breccias with phosphatic nodules, echinoderms, crinoids and undetermined ammonites. Some $100 \mathrm{~m}$ further to the west, the sequence is complete and the Maastrichtian shales also lie directly on the Garschella Formation. The upper boundary of the Wang Formation with the overlying Eocene Nummulites-rich limestones is a well-developed angular unconformity.

\subsection{Tertiary}

The Tertiary sequence is defined by a fining-upward sequence of quartzites, sandy limestones with Nummulites, and fine grained sandstones and shales. In the central part of the "alpine region", this sequence is transgressive onto the Wang Formation, whereas in the north it rests directly on the Schrattenkalk Formation. In the Sanetsch area (589071/134673), a few metres thick succession of quartzrich sandstones fill karstic open fractures in the Schrattenkalk, followed by dark grey limestones rich in Nummulites. South of Wildhorn, the Klimsenhorn Formation (Late Lutetian-Bartonian) represents the base of the Tertiary succession. This unit was traditionally called 'Nummulitenkalk', being an easily recognizable key level. From Les Audannes as far as the northern slope of

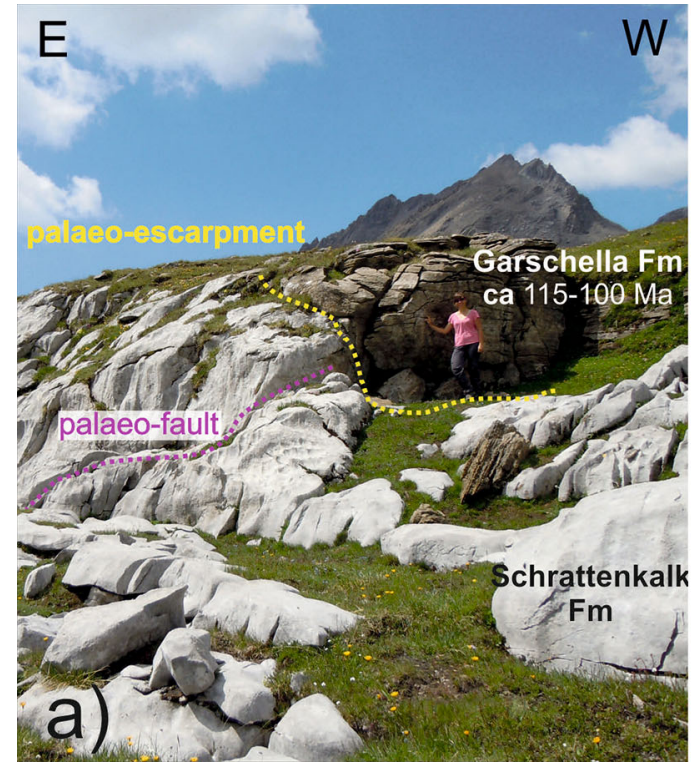

Fig. 8 Small and moderate scale faults. a Donin (594861/130115; for location, see Fig. 2): topographic step related to high angle NE-SW striking faults dislocating the top of Schrattenkalk Formation; the Garschella Formation then recovers the relief. b Plaine Morte (601513/134927; for location, see Fig. 2): Wang Formation seals

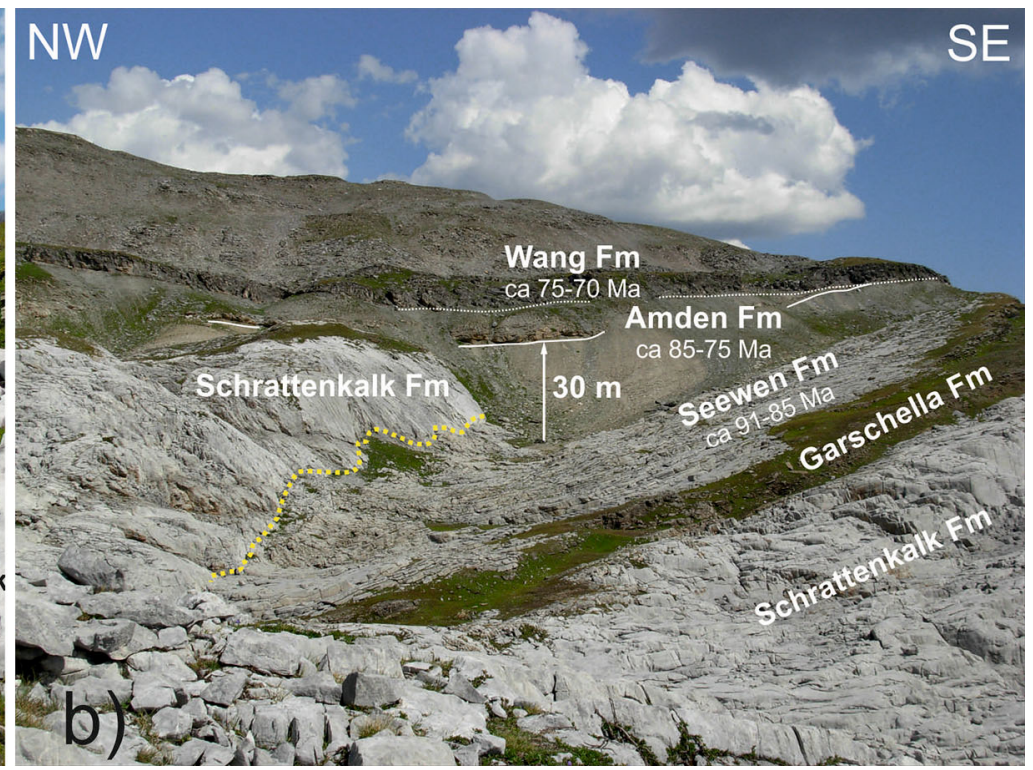

the growth fault related structure that developed in the Seewen and Amden Formations. The yellow dotted line traces the onlap of the Seewen Formation onto the palaeo-escarpment, which is a faultrelated irregular erosive surface sealed by marine deposits 
Wildstrubel, this formation is characterized by a package of 2-5 m of sandy limestones with large Nummulites (N. complanatus and N. perforates; Badoux et al. 1959).

The overlying Wildstrubel Formation (Bartonian-Priabonian) is represented by well-bedded fine grained sandstones with a typical orange weathering patina. This formation is about 40-60 m thick south of the Wildhorn mountain, whereas it is thicker (about 60-90 m) and more calcareous north of it, where bioclasts are abundant in some levels and intercalations of limestone are frequent. The lower limit is always sharp whereas the upper limit to the Globigerina Marl Formation in rather transitional in the Rawil area.

The Globigerina Marl Formation (Priabonian-Early Oligocene?) is represented by dark shales rich in planktonic foraminifera intercalated with lenses of grey glauconite-rich calcarenitic limestones (with chert) containing Nummulites and Heterostegines. The minimum thickness is about 50-70 $\mathrm{m}$ where the formation crops out between the Rawilpass and La Selle.

The overlying Helvetic Flysch (Early Oligocene) is represented by finely laminated and fine grained beige sandstones rich in white mica. At Follhore in the "northern region' (Figs. 3, 4a), the base of the Helvetic Flysch is characterized by polygenic matrix-supported conglomerates. This is the uppermost unit exposed in the Wildhorn Nappe and is overridden by the basal thrust of the Ultrahelvetic nappes.

\section{Late Cretaceous syn-sedimentary tectonics}

Many sedimentological and stratigraphic observations in Cretaceous units outcropping in the current study area are indicative of syn-sedimentary tectonics. In particular, clear evidence has been found at Plan des Roses, Les Audannes, Plaine Morte, and in the northern Wildstrubel-Rezli areas.

\subsection{Stratigraphic discontinuities}

The most diagnostic evidence for syn-sedimentary fault activity in the field is given by anomalous unconformable stratigraphic relationships and/or the absence of formations that would otherwise occur in a complete stratigraphic series. The major stratigraphic discontinuities of the succession in the study area are at the top of the Quinten, Helvetic Kieselkalk, Schrattenkalk, Garschella, Amden and Wang Formations. Here, we focus on the Late Cretaceous to Tertiary discontinuities.

The top of the Amden Formation is defined by an angular unconformity (Fig. 7) and has a clear lenticular shape (Fig. 6): its extension is limited to the north by the present Wildhorn-Schnidehorn mountain ridge and to the south by the unconformity at the base of the Wang Formation, which is well exposed at Plaine Morte (601730/ 135093). In detail, the Amden Formation crops out at La Selle but pinches out just south of Sex Rouge, indicating a growth-fault structure (Fig. 3, see Sect. 5.4). At Plan des Roses, the Wang Formation is thicker towards the basin (i.e. towards the south-east) where it overlies progressively older layers. Internal discontinuities in the Wang Formation are related to intra-formational slumps and to the resedimented depositional geometries of calc-turbidite levels. Towards the Wildhorn-Schniderhorn ridge, the Wang Formation pinches out quite dramatically at the level of the scarp of the Eaux Froides Fault (see Sect. 5.2), whose related escarpment is covered by a thin layer of TuronianSantonian limestones (Seewen Fm type) (Figs. 3, 6). At La Selle (Fig. 9b), slope instability was prolonged into the Turonian-Santonian, as recorded by slumps and internal unconformities in the Amden Formation and re-sedimentation of semi-consolidated limestone olistoliths typical of the Seewen Formation. Here the triangular shape of the basin may thus be attributed to prolonged syn-sedimentary fault activity. Finally, north of the Wildhorn-Schnidehorn ridge, the Amden and Wang formations are completely missing or markedly reduced, with these units either never having been deposited or else eroded away before sedimentation of the overlying Tertiary. There, the erosive surface at the base of the Tertiary units is represented by a para-conformity with the underlying Schrattenkalk Formation. North of the Wildhorn-Schnidehorn ridge, the Tertiary sequence is completely different: the Klimsenhorn Formation (former Nummulitenkalk) is absent but more calcareous beds are generally more common throughout the sequence. Reworked shells of gastropods and bivalves in impure neritic limestones suggest a mixed siliciclastic platform origin in shallow water, with occasional incursions of detritic terrigenous material during the Middle Eocene. It follows that not only the Cretaceous but also the Tertiary stratigraphic pattern is markedly different on both sides of the current Wildhorn-Schnidehorn ridge.

In the "alpine region" at Plan des Roses (597575/ 134701), Tertiary limestones and sandstones are preserved in erosive pockets in the Schrattenkalk Formation, defining an angular unconformity between the already NW-tilted Lower Cretaceous succession and the later Tertiary deposits. Badoux et al. (1959) and Wieland (1976) refer to these karstic pockets as "Siderolitique", and considered them to be Eocene in age.

\subsection{Syn-sedimentary faults}

The syn-sedimentary normal faults (palaeo-faults) of the Wildhorn Nappe have been active at different times and vary in their geometry, orientation and amount of 

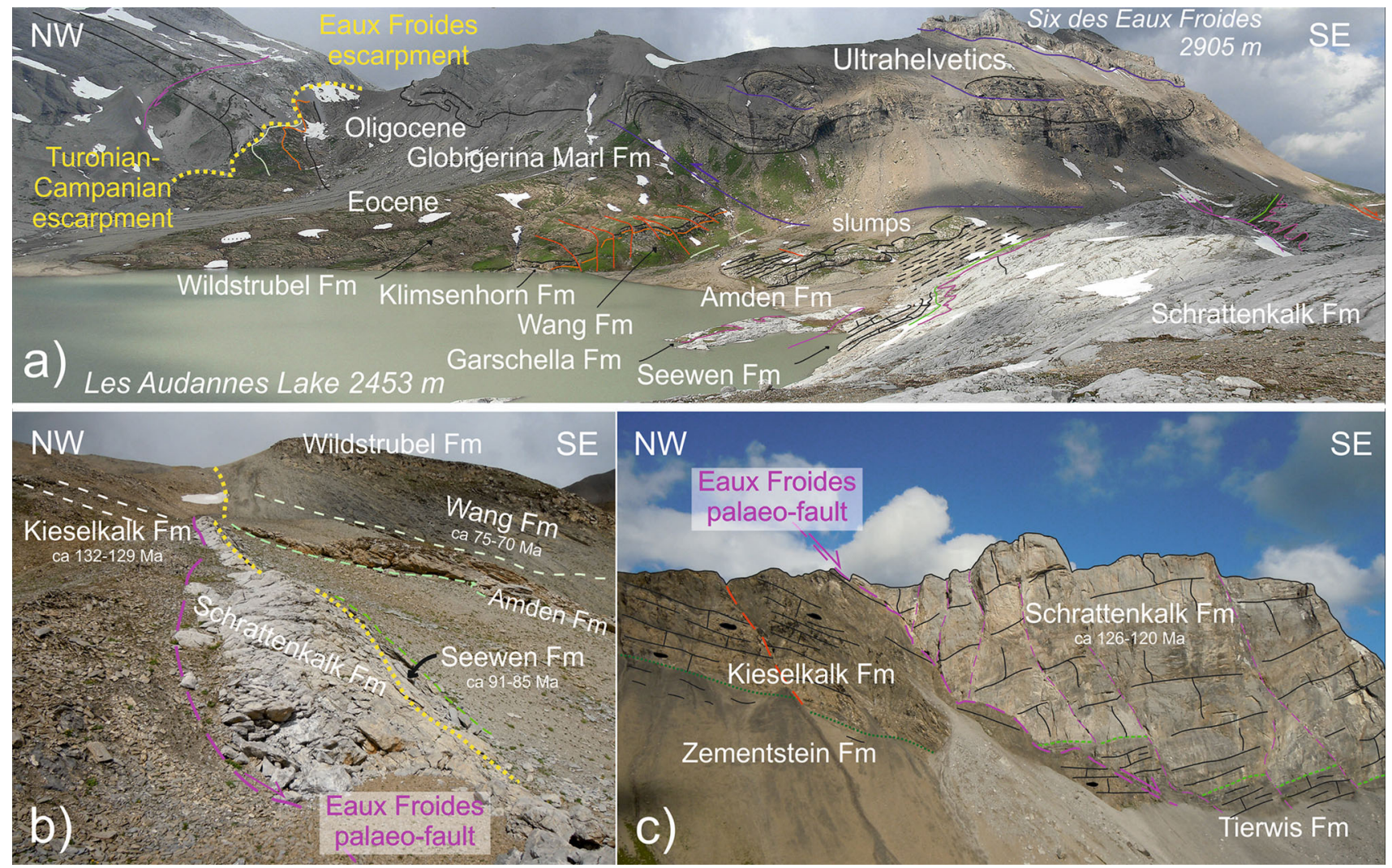

Fig. 9 Eaux Froides Fault (595993/132335; for location, see Fig. 2) a Les Audannes: onlap of the Upper Cretaceous and Tertiary sequence onto Lower Cretaceous rocks (i.e. Schrattenkalk and Tierwis Formations). Folds are related to the Alpine history, whereas slumps in the Amden Formation are Late Cretaceous soft sediment deformation. b La Selle (593990/131492): a slice of Schrattenkalk Formation is preserved in the footwall of the Eaux Froides Fault. Later, this slice is covered by a thin (about $1 \mathrm{~m}$ thick) veneer of

displacement. Most of the palaeo-faults are (E)NE-striking, and dip to the SE, but the present strike shows a range from ca. $030^{\circ}$ to $100^{\circ}$ (Fig. 2). Most faults strike approximately parallel to the regional fold axes and therefore are preserved in the dominantly upright limbs of the fold and thrust structure. However, their original orientation has probably been modified during later folding and thrusting, and block rotation and tectonic tilt cannot be excluded. Nevertheless, we observe a major trend of down-stepping of blocks to the south-east towards the outermost part of the continental margin, although a small number of antithetic syn-sedimentary faults do occur. At Plan des Roses and Plaine Morte, the system is defined by both synthetic and antithetic faults, which develop irregularly spaced horst and graben structures that are progressively onlapped by Upper Cretaceous and Tertiary deposits. A few faults also dip to the SSW, as clearly recorded in the Plaine Morte area and already reported by Lugeon (1914-1918) and Föllmi et al. (2007).
Seewen Formation pelagic limestones. Amden Formation marls and slumped limestones onlap the resultant palaeo-escarpment (yellow line). Violet lines palaeo-fault. $\mathbf{c}$ Panoramic view of the fault from the Sublage. The geometry of the fault (violet dashed line) is modified by later deformational events, because the Zemenstein Formation is preferentially reused as a decollément level during Alpine deformation

Three main sets of faults with different amounts of displacement can be distinguished: (1) small-scale faults with displacement of about 10-50 m; (2) moderate-scale faults with a displacement around 50-100 m; and (3) largescale faults with displacement in the range of 350-500 m. Set (1) affects the Garschella Formation and the lower part of the Seewen Formation. The progressive onlap that seals these faults is quite well defined (Figs. 7, 8, 9). The lateral continuity of these faults is only a few tens of metres and their spacing is also on a similar scale. Set (1) is associated with fractures infilled by karst-derived material (Garschella Formation). Sets (2) and (3) are represented by spaced and continuous faults that run approximately parallel for up to at least $15 \mathrm{~km}$. Fault spacing is some decametres for set (2) and about $1.7 \mathrm{~km}$ for set (3). Both sets are associated with growth fault structures, slumps, soft sediment intra-formational dykes of Seewen Formation and sedimentary breccias affecting the stratigraphic pattern of Seewen, Amden and Wang formations. 
In the Wildhorn profile (Fig. 3, profile A-B), set (3) is well represented. From north to south, we distinguish four main syn-sedimentary faults: the Sanetsch-Follhore, Eaux Froides, Sex Rouge-Donin and Chamossaire Faults. In detail, the field relationships suggest that these faults were active at slightly different times, so that set (3) can be subdivided into (3a): those active in the Turonian-Santonian (Eaux Froides Fault) and (3b): those active during the earliest Maastrichtian (Sex Rouge-Donin Fault).

The Eaux Froides Fault is the most important structure recognized in this study. It is a listric fault cross-cutting the Early Cretaceous Zementstein Formation up to the Late Cretaceous Amden Formation (Fig. 3, profile A-B), with a mapped strike length of about $15 \mathrm{~km}$. It has a maximum displacement of about $500 \mathrm{~m}$ and maintains a rather similar geometry along its whole strike length. This fault has been clearly deformed during the Alpine compressional phase (Fig. 9c) but the original syn-sedimentary fault displacement and related stratigraphic contacts and relationships can still be well established. The Eaux Froides Fault is associated with a roll-over anticline attendant on a half graben active during sedimentation of the Seewen and Amden Formations (i.e. during Turonian-Santonian time). This graben developed in the hanging wall of the Eaux Froides Fault is characterized by sediments showing growth fault-related geometries, with the Seewen and Amden Formations displaying thickness variations across the fault zones and intra-formational slumps verging towards the depocentre close to the fault. The Wang Formation subsequently lapped onto the still persistent submarine escarpment developed as the result of the earlier fault movement. South-east of the Eaux Froides Fault, the main graben is followed by a series of down-stepping halfgraben structures also characterized by growth fault-related geometries (e.g. at Donin and Chamossaire) in the Amden and Wang Formations. At Plan des Roses, in the immediate hanging wall of the Eaux Froides Fault, moderate scale synthetic and antithetic faults represent second-order conjugate structures directly related to the larger scale Eaux Froides Fault. The escarpment bounding the main graben and trending NE-SW is in detail crosscut by minor horsts and grabens, which strike NW-SE, perpendicular to the main graben. They are spaced a few $100 \mathrm{~m}$ apart and progressively onlapped during the Turonian-Santonian and Tertiary. Their orientation may reflect a (minor) component of extension also perpendicular to the main fault or, alternatively, local lateral collapse of the graben shoulder.

The Sex Rouge-Donin and Chamossaire Faults occur south of the Sex Rouge and crosscut the previous roll-back anticline associated with the Eaux Froides Fault, generating a new one (Figs. 2, 3, 7b, c). The south-eastern shoulder of the half-grabens related to the Early Maastrichtian faults outcrop between the Sex Rouge and the Chamossaire area and on the western side of Wildstrubel (i.e. Sex RougeDonin Fault in Fig. 7). There the Wang Formation lies unconformably on top of the silicified Schrattenkalk and Tierwis Formations (Figs. 6, 7b, c), which were clearly exposed and eroded during part of the Early-Late Cretaceous. These faults are quite steep and record different amount of displacement, with the Sex Rouge-Donin Fault showing about $450 \mathrm{~m}$ and the two faults in the Chamossaire zone each having an offset of about 50-100 m (Fig. 3, see also Sect. 6.1). Syn-sedimentary breccias, resting in pockets on the steep Schrattenkalk escarpments, were covered already in the Early Maastrichtian by the Wang Formation (e.g. Fig. 12a, b). The rotation of the half-graben blocks in a domino-like structure (Sect. 6.1) was favoured by gliding along the flatter portion of the master fault lying in the marly units of the Zementstein Formation. These faults were already completely sealed during the Maastrichtian, with the upper part of the Wang Formation and the Tertiary succession subsequently simply infilling the basin topography.

In the "frontal region", moderate-scale set (2) faults that influenced the facies and thickness distribution of Eocene deposits also occur. These syn-sedimentary faults in the "frontal region" are characterized by displacements of around 70-100 m, with the resultant domino-like structure sealed by the Globigerina Marl Formation. These faults are also cross-cut by an Alpine thrust that repeats the Lower Cretaceous series. The syn-sedimentary fault spacing is quite close (ca. $100 \mathrm{~m}$ ), suggesting that the basal decollément to these faults may have been relatively high in the stratigraphic pile, probably in the Zementstein Formation. Just north of the Sanetsch lake (Fig. 13), these faults, and the palaeo-escarpments related to them, are older than the Eocene limestones and mixed siliciclastic rocks that onlap onto them. This suggests that these faults may also be related to the Cretaceous phase documented above, rather than to a new period of Eocene activity, as proposed by Herb (1988) and Menkveld-Gfeller (1995). In our interpretation, the variation in thickness between hanging wall and footwall of the Eocene deposits is related to filling and sealing of already existing fault escarpments and to differential compaction rather than to Eocene fault activity, as supported also by Bover-Arnal et al. (2011). Nevertheless, syn-sedimentary fault activity may well be younger to the north-west, towards the European continental shelf.

\subsection{Facies distribution}

The units developed during syn-sedimentary faulting are the Garschella, Seewen, Amden and Wang Formations (south of Sex Rouge). Contrary to previous interpretations (Herb 1988; Menkveld-Gfeller 1995), we consider the upper part of the Wang Formation and the Tertiary units to 

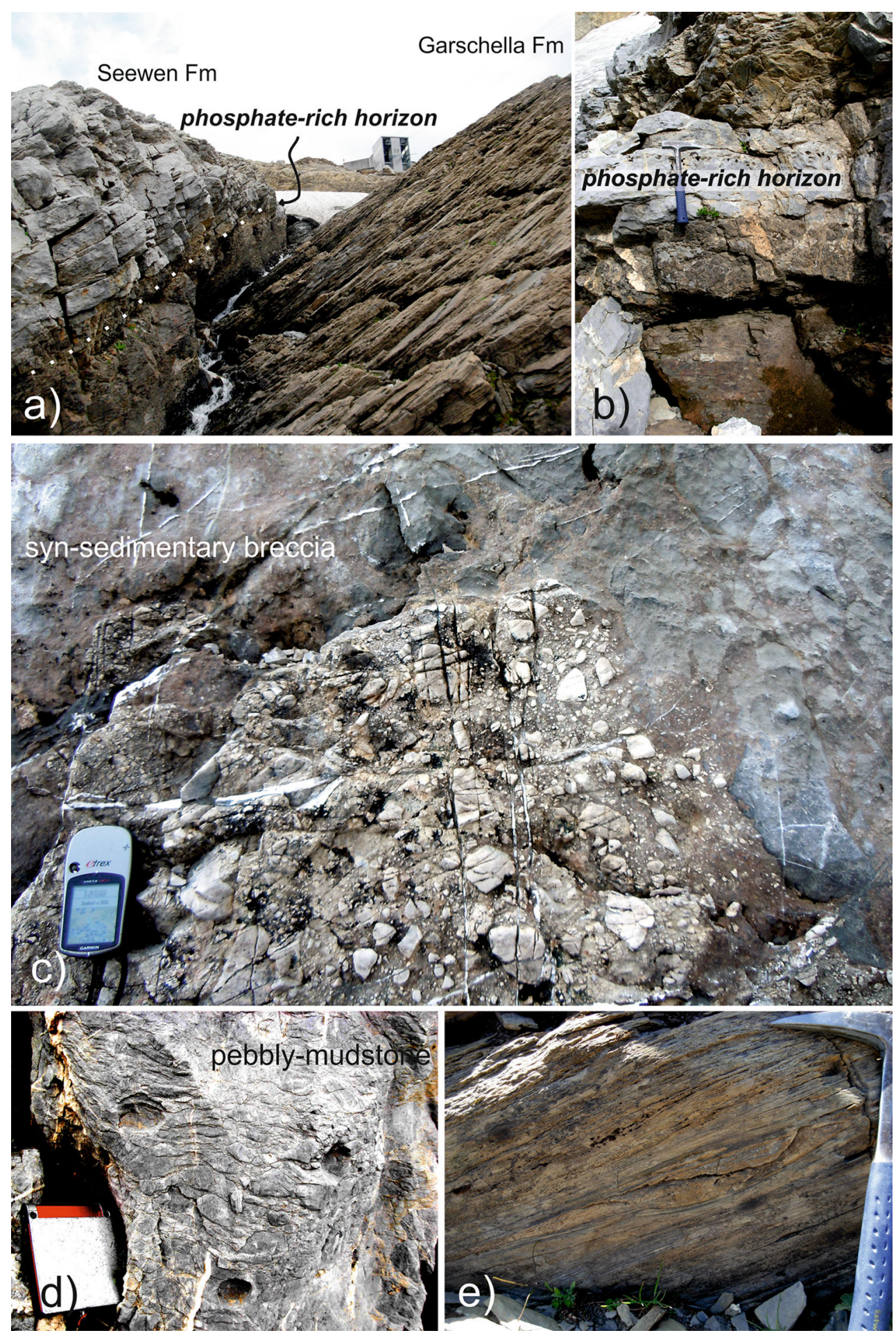

Fig. 10 Examples of facies changes and variations (for location, see Fig. 2). a, b Rawilpass (593555/137131): complete transgressive sequence in the Early Turonian; black shales are overlain by phosphate-rich conglomerates and pelagic limestones with $\mathrm{Fe}-\mathrm{Mg}$ oxides and phosphatic horizons indicating reduced sedimentation rates. c Les Audannes north (595987/133145): unsorted sedimentary breccia overlying the escarpment surfaces. d Les Audannes south

(595829/131514): breccia composed of clasts of the Seewen Formation and matrix that probably originated after in situ brecciation of the Seewen Formation veneers sedimented on the palaeo-escarpment surface. e Les Audannes north (595829/131514): plane parallel lamination characterized by internal erosional surfaces in calcarenitic levels of the Amden Formation 
post-date significant palaeo-fault activity. Fine-grained deposits like the pelagic limestones of Seewen Formation are interpreted to have been deposited in situ and therefore not re-sedimented. The occurrence of pyritic nodules and phosphate horizons, which mainly crop out at Sex Rouge and Les Audannes, is considered to be indicative of condensed pelagic units. Conglomerates with phosphate clasts only occur in condensed conglomerate limestones at the base of Seewen Formation, which could indicate that phosphate-rich crusts have been eroded in places and reworked by mass flows during marine transgression (Fig. 10a, b). Syn-sedimentary breccias are preserved in the flatter areas of the escarpment immediately below the onlapping pelagic deposits generally belonging to the Seewen Formation. They can be either (1) polygenic, bearing clasts of the units exposed at the palaeo-escarpment in an unsorted matrix (Fig. 10c), or (2) an intraformational syn-sedimentary breccia (Fig. 10d), with matrix and clasts having the same composition, suggesting in situ reworking of the veneer covering the escarpment surface. Fine-grained graded calcarenites with a lenticular shape occur in the Amden and Wang Formations in the hanging wall of syn-sedimentary normal faults. Currentrelated facies are defined by erosive pockets filled by graded deposits and internal angular unconformities. This indicates that re-sedimentation happened in tectonically depressed areas and probably along channelized turbiditic fans (Fig. 10e). Since thicker and re-sedimented units occur in the hanging wall of the palaeo-faults, the facies distribution is interpreted as being directly related to the palaeo-fault array. Other internal unconformities may be due to slumping (see Sect. 5.7).

\subsection{Growth fault-related structures}

Wedge shaped basins reflect the syn-sedimentary activity of moderate- to large-scale faults, with thickening of the units towards the fault. The tilt of the hanging wall blocks is generally associated with a local stratigraphic gap on the shoulders of the resultant half-graben structures whereas, as reported above, re-sedimentation occurs close to the normal faults. Good examples of such structures crop out at Rezli, Plaine Morte, Donin and north of Sex Rouge (Fig. 7a, c). Growth fault-related structures occur in the Seewen, and part of the Amden and Wang Formations, establishing that the main period of fault activity was in the Late Cretaceous. The Garschella Formation (Early Cretaceous) is only influenced by small-scale syn-sedimentary faults that do not produce extensive growth-fault related structures, except at the Plaine Morte, where the Garschella Formation reaches its maximal thickness (ca. $30 \mathrm{~m}$; 601519/134514). In the same location, Upper Cretaceous pelagic and re-sedimented deposits clearly onlap the palaeo-fault and its related escarpment, showing progressive sealing and prolonged fault activity (Fig. 8b).

\subsection{Sedimentary dykes}

In places sedimentary dykes are organized largely subparallel to the palaeo-fault or to the resulting palaeoescarpment. Sedimentary dykes can develop by infilling of subaereal fractures and karst dissolution channels or as Neptunian dykes, with an infill of subaqueous material (Garschella-type and Seewen Formation sediments). However, in both cases, the location and geometry of the sedimentary dykes may be controlled by pre-existing joints and minor faults. In particular, during exhumation of the Schrattenkalk platform, a quite diffuse and small-scale faulting is recorded in the area (set 1) and the distinct preferred orientation of both these faults and the sedimentary dykes within the uppermost exposed Schrattenkalk Formation (Fig. 11) presumably reflects the stress field in the area at that time. In the south-easternmost outcrops of the Schrattenkalk Formation, karst- and Garschella-related material fill NE-striking fractures in the underlying platform limestones (Fig. 11), indicating subaereal exposure, accompanied by small-scale normal faulting and karstification, prior to the final drowning of the Schrattenkalk platform and the transition to pelagic conditions (Garschella Formation). West of Sex Rouge, intra-formational synsedimentary dykes have also been found affecting the base of the Seewen Formation.

\subsection{Escarpments}

The escarpments form only on those portions of the faults that were exposed at the sea floor and, therefore, to erosion. Now they are partially covered by Upper Cretaceous to Eocene deposits (Figs. 4, 7, 8, 9). The major erosive surfaces can be traced over several kilometres (Fig. 2). In places, the scarp itself is covered by thin patches and veneers of orange amorphous silica, often forming aggregates of small $(2 \mathrm{~mm})$ whitish spheres of silica. Selective silicification of shells is also observed in the grainstones at the top of the Schrattenkalk Formation. Similar to what has been observed on Apennine escarpments by Santantonio et al. (1996), silicarich pelagic limestones (Kieselkalk, Tierwis, Seewen and Wang Formations) or sandstones (Garschella Formation and Tertiary units) can be the source of silica-rich fluid, which migrated during burial and diagenesis in the direction of the more porous Schrattenkalk grainstones within the fault zone and/or escarpment surfaces. Some of the crusts on the smallscale escarpments are also likely to be karst-related, most probably developed during exhumation of the Schrattenkalk platform during early stages of faulting. As outlined by Föllmi and Gainon (2008), the demise of the Urgonian 


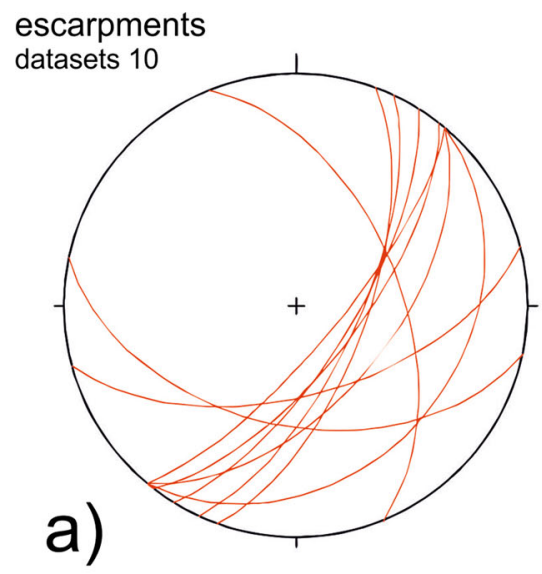

dykes

datasets 78

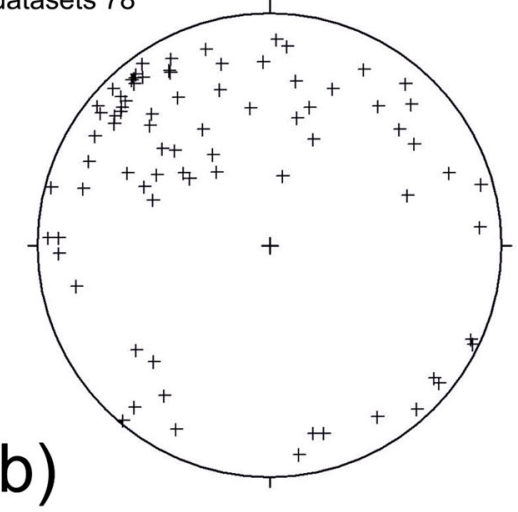

Max.value $9.92 \%$

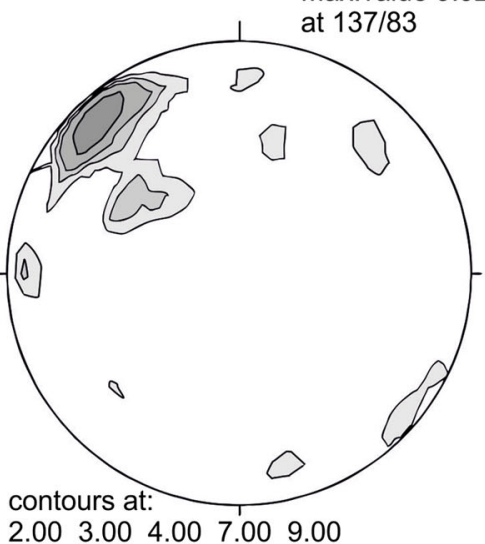

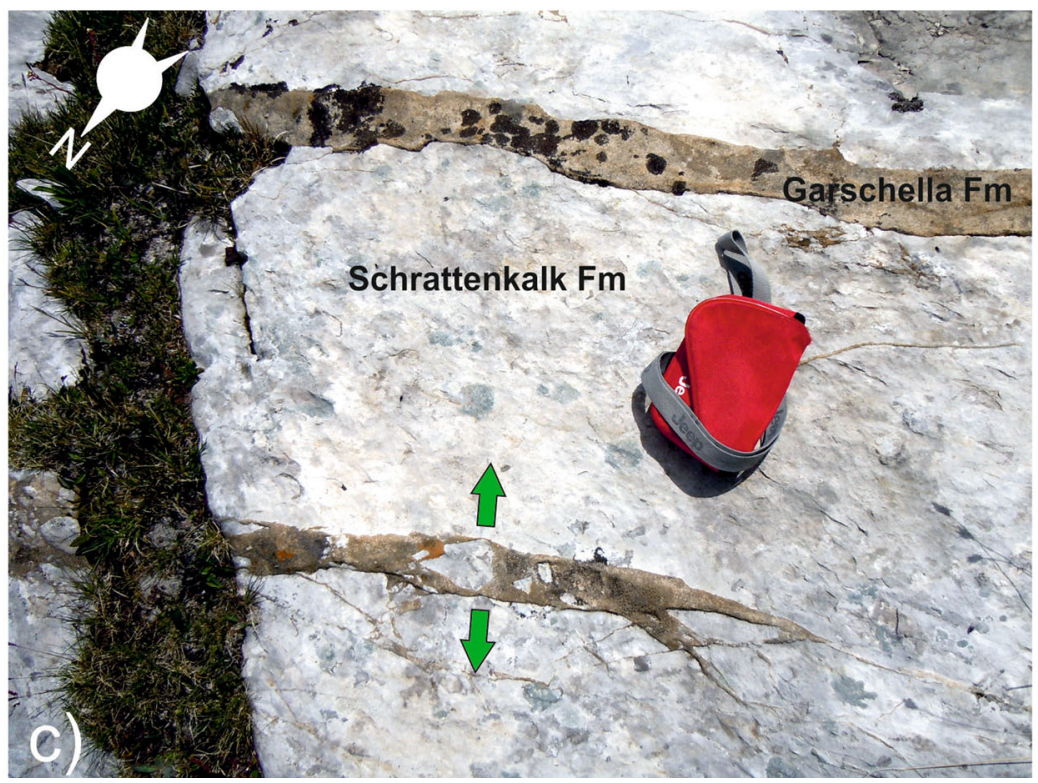

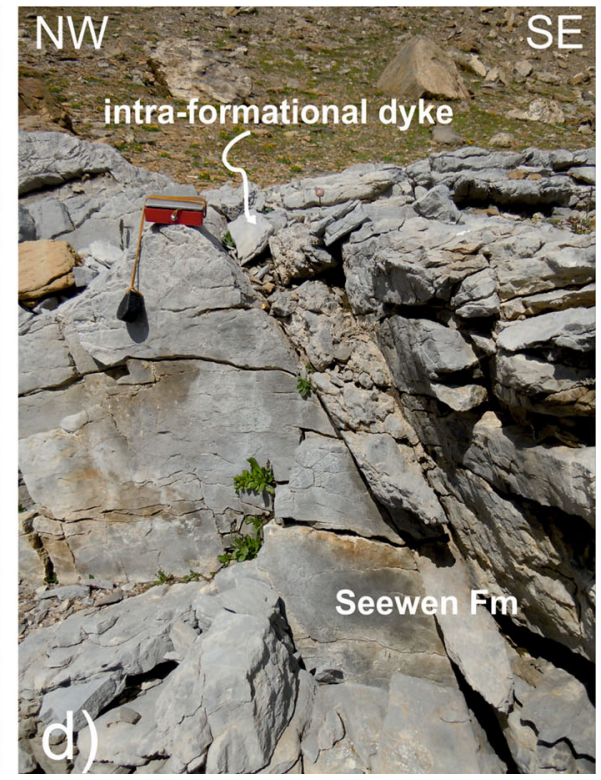

Fig. 11 a Great circle plots of the orientation of escarpments directly measured in the field. b Poles to the walls of intra-formational dykes (lower hemisphere, equal area projection, pole diagram and contour diagram). Most of the dykes strike NE-SW. c Donin (594861/130115; for location, see Fig. 2): SW-dipping karstic dykes into Schrattenkalk Formation. d La Selle south (594695/131203; for location, see Fig. 2): intra-formational dyke infilled by brecciated Seewen Formation pelagic deposits platform was initially related to extensional movements characterized by $1-5 \mathrm{~m}$ displacements recorded on smallscale blocks [about 20-50 $\mathrm{m}$ across; our set (1) faults, Fig. 8a], later followed by more important displacements on larger, more widely spaced faults throughout the Cretaceous [our set (2) and set (3) faults].

The moderate- (Fig. 8b) and large-scale faults (i.e. Fig. 9) are characterized by erosive surfaces defined by smooth promontories and embayments, as at the Col des Eaux Froides (596862/133847; see also Fig. 4). These marine erosive escarpments are similar to what has been described by Rankey and Doolittle (2012) for the Little Bahama Bank. In places, the resultant geometry is determined by morphological steps on which syn-sedimentary breccias were deposited (Figs. 10c, d, 12b). At Donin, Les
Audannes, Plan des Roses and northern Wildstrubel, good examples of escarpments completely covered by pelagic deposits of the Seewen, Amden and Wang Formations crop out (Fig. 7). The contact is quite sharp between the karstified Schrattenkalk and the pelagic limestones. The scarp surface is usually irregular, suggesting regressive erosion and sculpting of former fault planes. The displacement on the faults is commonly about $5-25 \mathrm{~m}$ and the spacing between faults is about $50-100 \mathrm{~m}$.

The footwall escarpment of the Eaux Froides Fault developed steep rounded cliffs in the Schrattenkalk Formation, a rough but shallower dipping surface in the more marly limestones of the Tierwis Formation, and again a steeper surface in the Kieselkalk Formation, where there is the passage from escarpment to palaeo-fault. At the contact 

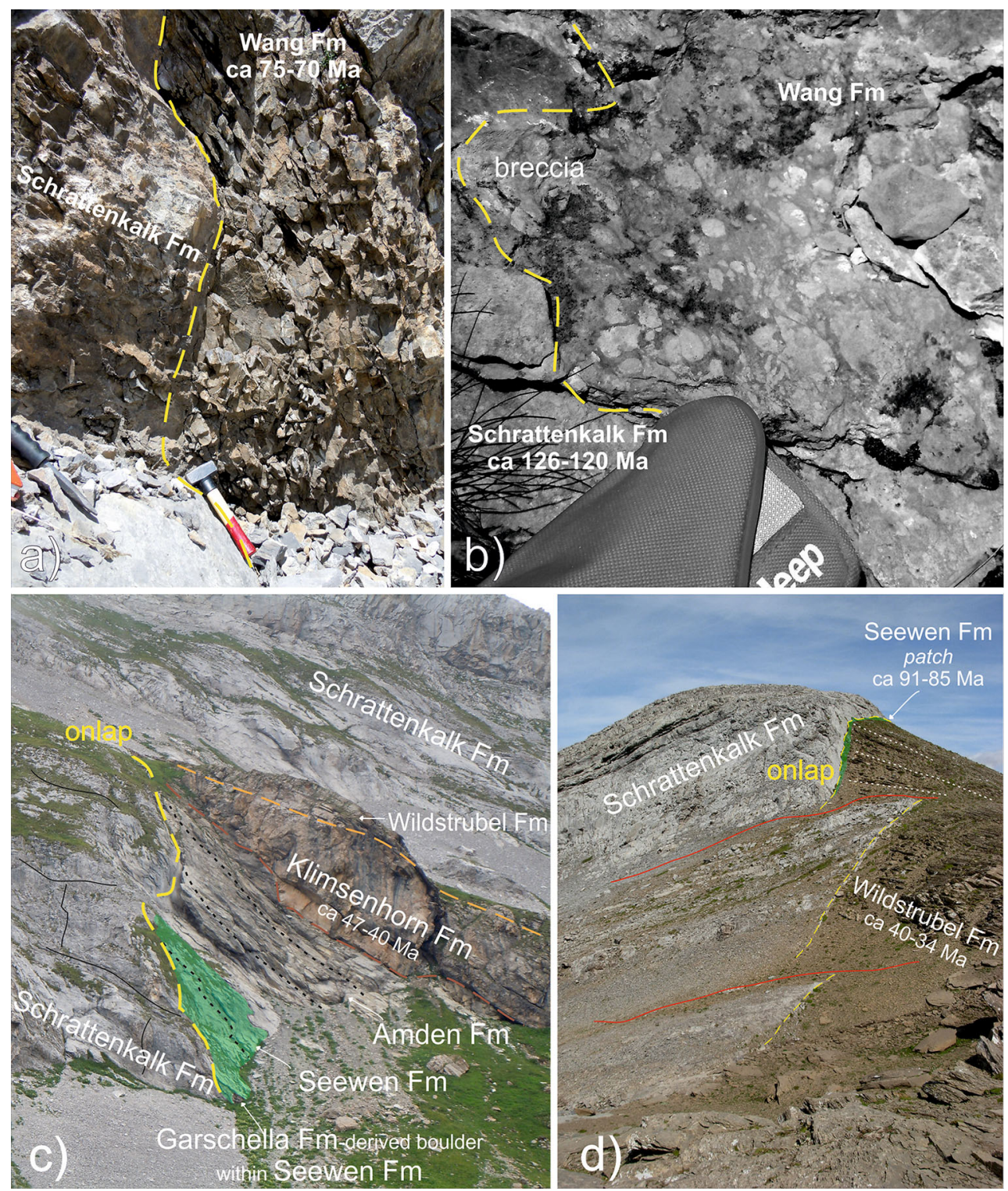

Fig. 12 Details of palaeo-fault escarpments at various localities (for location, see Fig. 2). a, b Southern slope of Sex Rouge (595313/ 130693; see Fig. 7b, c for panoramic location). a Step-wise geometry of the escarpment resulting in a subvertical undulating surface (yellow line) that has been silicified. b Syn-sedimentary breccia preserved in

with the Schrattenkalk and Tierwis Formations, the escarpment is typically covered by a thin veneer (ca. $5-20 \mathrm{~cm}$ ) of pelagic sediments with Globotruncana (Seewen Formation) resting directly on breccias with clasts derived from the Schrattenkalk and Tierwis Formations (Fig. 10) and with microforaminifera in the matrix of the breccia. These breccias have a lenticular shape, are not laterally continuous, and possibly represent different generations. They are later progressively onlapped by sediments of the Upper Cretaceous Amden and Wang Formations (Fig. 9b). In the topographically highest areas, the flatter parts of the escarpment under the onlapping deposits. $\mathbf{c}$ Plan des Roses (598727/136183): Amden Formation together with the Tertiary succession onlap the previously formed escarpment. d Mittaghorn crest (599366/136781): the escarpment is displaced by late Alpine transtensive faults

the escarpment is directly overlain by Eocene deposits (Wildstrubel Formation; Figs. 9, 12d). In the "frontal region", the Upper Cretaceous succession is absent but the Lower Cretaceous succession is affected by a SE-dipping synthetic normal fault system transected by a pre-Eocene angular unconformity.

\subsection{Slumps}

Slumps occur at the base of the Seewen Formation as well as within the Amden and Wang Formations. Their 
vergence is always towards the local depocentre. In the Donin area (594278/130092), the base of the Seewen Formation glides for a few tens of metres on the contact with the Garschella Formation moving towards the depocentre and generating syn-sedimentary folds verging towards the palaeo-fault. This gliding and slump folding suggests denudation of a steep submarine escarpment. The top of the Garschella Formation generally acts as the synsedimentary gliding surface, marking the base of the slumps in the Seewen Formation (Fig. 7). The youngest layers sedimented on top of the slumped beds are preserved in the synclines of the slumps, recovering the topographic relief and post-dating slumping (e.g. as seen at Donin, north of Wildstrubel and west of Rezli; Fig. 7a). Intraformational slumps occurring within the Amden Formation have been observed in many places. The most spectacular outcrop is at La Selle (Fig. 9b) but clear examples are also seen at Les Audannes (Fig. 9a) and Plaine Morte, as already described by Villars (1989).

\section{Discussion}

\subsection{Stratigraphy and structure}

In this section, we discuss the interaction between faulting and facies distribution. Stratigraphic discontinuities may be related to (1) palaeo-fault and palaeo-escarpment surfaces, which are defined by onlap of the draping units, (2) erosional surfaces (and especially angular unconformities) related to tectonics and (3) stratigraphic gaps, which could, however, also be caused by non-tectonic events (e.g. sea-level changes, carbonate production, current circulation, etc.).

The top of the Schrattenkalk Formation (Early Aptian) is affected by widely distributed minor faulting and fracturing, with lithified soil deposits that fill these fractures demonstrating an interplay between both tectonic and karstic/sedimentary processes. This event appears to have preceded deposition of the Garschella Formation (Late Aptian-Middle Turonian) and the erosive (and karstified) surface probably developed due to exposure and subsequent (possibly marine) erosion of the Schrattenkalk platform. The transitional succession at the top of the Garschella Formation may be due to sea-level fluctuations (Föllmi and Gainon 2008) but it could also reflect regional subsidence influenced by ongoing normal faulting (Fig. 8). The probable interaction between these two processes (i.e. sea-level change and normal faulting) finally drove the area into a pelagic setting during the Turonian, causing the final drowning and demise of the platform. In the Wildhorn Nappe, Cretaceous sandstones were only deposited during this Aptian-Albian exhumation of the European carbonate platform. Rare exotic clasts of metamorphic rocks occur in the Garschella Formation and Föllmi and Gainon (2008) report an ${ }^{40} \mathrm{Ar} /{ }^{39} \mathrm{Ar}$ age for white mica from a mica schist clast of ca. $330 \mathrm{Ma}$. This indicates that the Variscan metamorphic basement was locally exposed at this time, possibly as a result of normal fault activity similar to the early syn-sedimentary faults of set (1). This eroded basement material was then transported and deposited in the portion of the passive margin now included in the Wildhorn Nappe, suggesting that the European Mesozoic margin sequence was not invaded by "orogenically derived" sediments until the Eocene.

The facies distribution (Sect. 5.3) indicates an overall gradual deepening of the basin south of the WildhornSchniderhorn ridge and the Eaux Froides Fault, with Upper Cretaceous pelagic deposits only preserved in the south (Fig. 14). The top of the Amden Formation is defined by a tectonically related unconformity (Fig. 7), due to the activity of syn-sedimentary faults and the generation of growth-fault geometries. The relief related to this tectonic activity was recovered and sealed by the Wang Formation during the Early Maastrichtian.

In summary, the area of the future Wildhorn Nappe experienced four tectonic and sedimentary stages during Late Cretaceous extension. (1) Post-Cenomanian disruption and exhumation of the Schrattenkalk platform was related to distributed normal faulting, which contributed to the initiation of karst erosion on topographic highs and sedimentation in topographic lows. (2) During the Turonian-Santonian and following a marine transgression, the area experienced more localized normal faulting accompanied by subsidence and slope instability directed towards the fault scarps. A transition from distributed to more localized faulting is observed, related to a final stage in the evolution of the Cretaceous extensional process. The facies and thickness of subsequent post-Santonian sediments reflect a passive adaption to the pre-existing topography of the sea floor, established during the earlier tectonic movements. The bathymetric relief inherited after this extensional Cretaceous event is recovered partially during the sedimentation of the Wang Formation to the south. (3) Early Maastrichtian faulting in the area south of the Sex Rouge. (4) Post-Maastrichtian NW-directed tilt and erosion.

At the base of the Tertiary sequence, the stratigraphic gap and its related angular unconformity record an important event in the dynamics of the basin that has similar characteristics throughout most of the Helvetic domain (Herb 1988; Menkveld-Gfeller 1995; Kempf and Pfiffner 2004; Bover-Arnal et al. 2011). This unconformity, formed during the Late Cretaceous-Early Eocene, is marked by the beginning of siliciclastic sedimentation, which may reflect the onset of a new tectonic phase related to the Late Oligocene-Miocene Alpine orogeny (Kempf 
and Pfiffner 2004). In the south-eastern part of the "alpine region" of the study area, the Cretaceous-Tertiary unconformity shows an angular discordance of ca. $10^{\circ}$ towards the north-west, reflecting post-Maastrichtian tilt. This tilt is most likely due to differential compaction along previously formed structures (i.e. the Eaux Froides Fault escarpment). Although it could potentially also be caused by later (Palaeocene-Early Eocene?) tectonics, there is no evidence for this in the field. The arguments against active Eocene tectonics rather than passive adaption to pre-existing topography established during Late Cretaceous syn-sedimentary tectonics are based on observations suggesting that the modern Wildhorn-Schnidehorn Alpine topographic ridge was a former Cretaceous high, bounded to the south-east by an important syn-sedimentary fault-the Eaux-Froides Fault-whose activity is clearly confined to the Late Cretaceous and cannot be responsible for the postMaastrichtian tilt. As observed at Plan des Roses, this unconformity suggests that the Cretaceous edifice was already tilted and dipping to the north-west before the Eocene. North of the Wildhorn-Schniderhorn ridge, the pattern of facies distribution during initial Tertiary sedimentation still followed the pre-existing (Late Cretaceous) palaeogeographic features. A Palaeocene or even early Eocene age (i.e. pre-Klimsenhorn Fm) for the latest synsedimentary tectonic activity and escarpment development cannot be excluded. However, there is no direct evidence for this, whereas, as documented extensively in the present paper, and as suggested by the palaeogeographic interpretations of Bover-Arnal et al. (2011), there is very clear evidence for activity in the Late Cretaceous. Because of this, we conclude that the Tertiary sequence seals the inherited and long-lived Late Cretaceous relief, whereas this geometry was previously interpreted by Günzler-Seiffert (1952), and later by Kempf and Pfiffner (2004), to be due to a large Tertiary fault. The Eaux Froides Fault was referred to as the Hohgant-Rawil Fault by Kempf and Pfiffner (2004), who described this important structure as being continuous to the east of Thun in Central Switzerland for a distance of ca. $70 \mathrm{~km}$. They considered this fault to be active in the Eocene, whereas in the current study area we argue that its activity was older, in the Late Cretaceous.

The well-documented evolution of the Tertiary stratigraphic pattern published by Bayer et al. (1983), Herb (1988) and Menkveld-Gfeller (1995) can be related to deepening of the basin towards the south and tilting towards the north due to the progressive formation of halfgrabens stepping down to the south-east. However, in the area mapped in this study, there is no unequivocal evidence to indicate activity of Tertiary syn-sedimentary faults. Bayer et al. (1983, their Fig. 14), show a clear example of onlap onto an escarpment and not of a fault that was still active at the time of Eocene deposition. The surface is very irregular and mimics the soft and hard layers, and the (sedimentary) breccia (with a matrix of Eocene age?) is only in the hanging wall, which is not expected for a fault breccia. This escarpment was developed as a fault, but it has been eroded back and the topography draped and sealed by later sedimentation. The topography was still present in the Eocene but there is no evidence in the sketch of Bayer et al. (1983, their Fig. 14) that faulting itself was still active in the Eocene.

In field examples such as Fig. 13, it is obvious that fault displacement in Cretaceous units must be older than the Late Maastrichtian-Early Eocene gap represented by the unconformity, which truncates these faults without any discernible offset. Menkveld-Gfeller (1995, her Fig. 8) also shows that faults were already pre-existing but argued that they were reactivated in the Eocene, with increasing and progressive displacement accumulating along parallel normal faults. In her sketch, faults were not affected by erosion and their geometry was preserved, whereas field evidence suggests that the activity of these faults was confined to the Late Cretaceous rather than still being active (or reactivated) in the Tertiary. The Cretaceous faults produced marine escarpments covered locally by veneers of onlapping units, syn-sedimentary breccia and, in places, marked by silicification of the exposed palaeo-fault and palaeo-escarpment surfaces. Nothing similar was documented on the faults studied by Herb (1988) and Menkveld-Gfeller (1995), nor was it recognized in the field during the current study. Local fault reactivation cannot be excluded and might be expected. However, at least in the Wildhorn Nappe, we conclude that any Tertiary faulting is much less widespread than that developed in the Late Cretaceous. If there was any syn-sedimentary activity during the Tertiary in the study area, it must be confined to the "frontal region" (i.e. Follhore; Figs. 2, 15) or (palaeogeographically) north of the Wildhorn Nappe, with faulting becoming younger towards the more external domain (i.e. the European foreland). Unfortunately, the Upper Cretaceous succession in the Diablerets and Doldenhorn Nappes is quite discontinuous or completely lacking, so there is little or no sedimentary record that would enable us to recognize the influence of Cretaceous tectonics on the more external passive margin. Kempf and Pfiffner (2004) relate the Tertiary faulting to the flexure of the European plate during north-westward thrusting of the Alps, but its development may be more important towards the more external foreland basin than in the area of the future Wildhorn Nappe.

\subsection{Origin of Late Cretaceous syn-sedimentary faults}

Föllmi and Gainon (2008) attributed these faults to either frontal collapse of the Schrattenkalk platform or to 

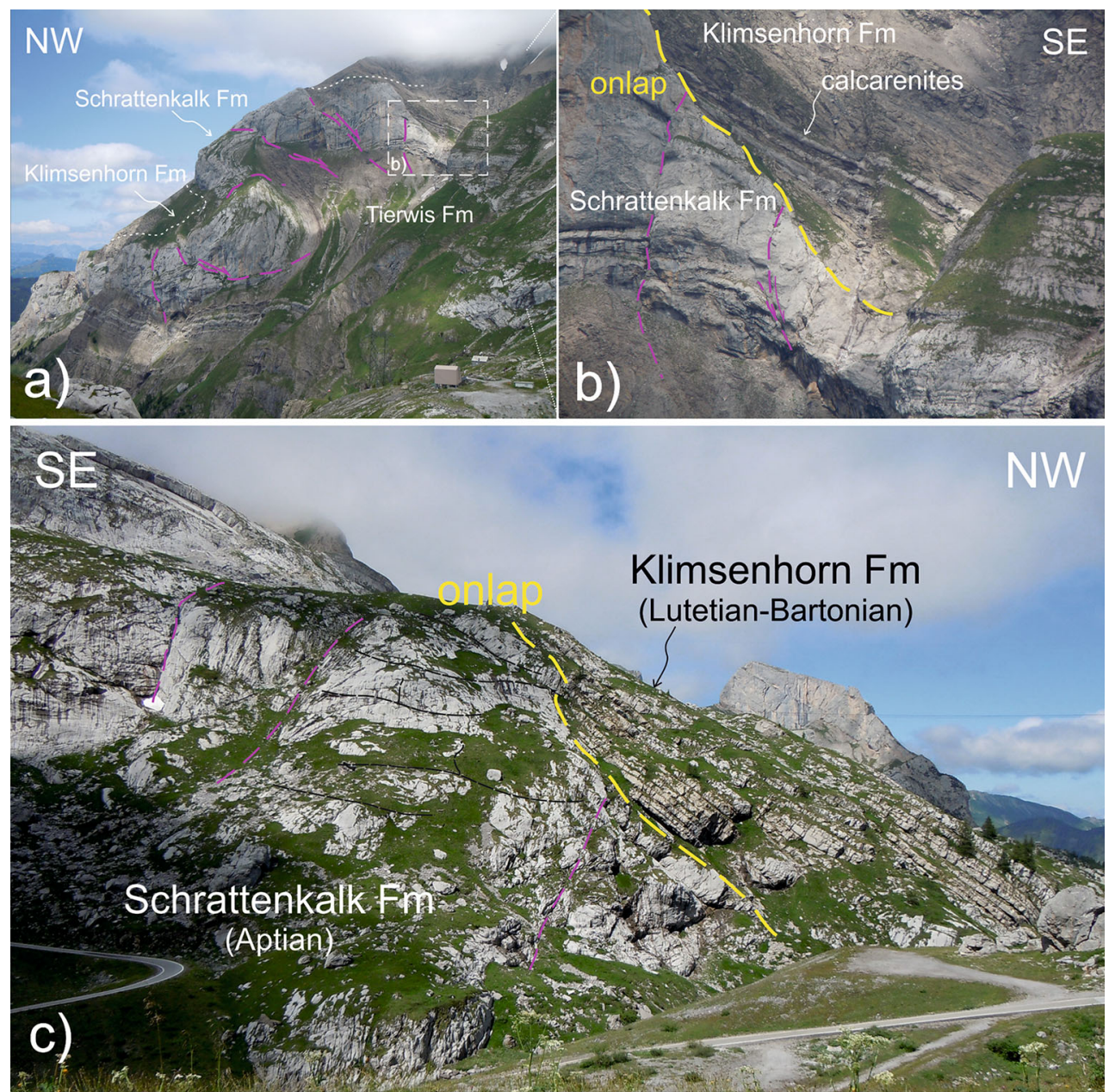

Fig. 13 Palaeo-escarpments sealed by Tertiary formations-examples from the Sanetsch area (for location, see Fig. 1): a anticlinesyncline structure affected by normal faults (violet dashed lines). The top of the Klimsenhorn Formation seals the faults (dotted orange line). b Normal palaeo-faults that terminate beneath the erosive surface onlapped by the Klimsenhorn Formation deposits, demonstrating that faulting is older than Eocene. c Angular unconformity between Lower Cretaceous and Tertiary beds (588805/134483) tectonics, but left the question still open. In the case of frontal collapse of the Schrattenkalk platform, faults should change their strike and displacement from place to place in response to lithological heterogeneity (i.e. change of facies, thickness and load) of the collapsing platform edge. In this case, fault continuity and the amount of displacement should be more variable than what is observed. Furthermore, the more competent stack of platform carbonates should glide on the closest marly or otherwise weak level (i.e. the Drusberg Member, Tierwis Formation). However, Late Cretaceous syn-sedimentary faults cut through the Tierwis and Kieselkalk Formations to reach deeper levels, thereby cross-cutting a larger portion of the stratigraphic pile and suggesting that the whole crust may have been in extension and not just the uppermost layers.

In addition, the gradual transition towards the deeper basinal area to the south-east of the European margin was not bounded by a single fault capable of causing lateral gravitational collapse (Fig. 15). During the Late Cretaceous, the area was characterized by a series of halfgrabens, which formed progressively through time. In the sedimentary succession of the Wildhorn Nappe, the Upper Cretaceous pelagic facies units, which are indicators of deeper water with respect to the euphotic carbonate platforms, only outcrop south of the Wildhorn-Schnidehorn ridge. However, normal faults of modest displacement [i.e. fault-set (2)] also occur on the Wildhorn-Schnidehorn ridge and north of it, suggesting a broad regional distribution of faults far from the master fault (i.e. the Eaux Froides Fault; Figs. 2, 3, 15). This suggests a tectonic origin for the whole Cretaceous syn-sedimentary fault system, rather than gravitational collapse as the driving process.

In the literature, the interpretation of such structures has been restricted to published profiles but without extensive documentation or discussion. For example, in the 
"southern region" of our study area, the cross-sections published in the Geological Map of Switzerland (Badoux et al. 1959, 1962) suggest syn-sedimentary activity on some of the SE-dipping faults. In particular, the crosssection of the Prabé Mount (Badoux et al. 1959) shows a blind normal fault that controls the thickness distribution of the Upper Jurassic and Cretaceous deposits and terminates in the Wang Formation (Early Maastrichtian). If normal faulting reflects tectonic activity rather than gravitational collapse, this implies either long-term activity (i.e. "persistent" faults in the sense of Günzler-Seiffert 1942) or fault reactivation in two post-breakup extensional events (i.e. Late Jurassic and Late Cretaceous).

\subsection{Reactivation during Alpine collision}

The occurrence of palaeo-faults, palaeo-escarpments, unconformities, thickness variation, and facies changes related to syn-sedimentary tectonics resulted in a truly $3 \mathrm{D}$ geometry prior to Alpine orogenesis and these irregularities may have strongly influenced the development of the Helvetic nappes. Palaeo-faults and palaeo-escarpments have not been specifically considered as pre-existing structures that could have influenced the formation of the Wildhorn Nappe. Herwegh and Pfiffner (2005) did however interpret the Doldenhorn Nappe as an inverted basin, with the Doldenhorn thrust representing an old reactivated syn-sedimentary fault. They also noted that similar ramps might have resulted in frontal anticlines of the Wildhornand Gellihorn Nappes and prevented the formation of stretched large-scale inverted limbs. In the Wildhorn Nappe, the SE-dipping normal faults parallel to the fold axis were interpreted by Ramsay et al. (1983) as reflecting the boudinage of fold limbs during folding, assuming an initial approximately layer-cake succession. In the profile of Ramsay et al. (1983), SE-dipping normal faults occurring in the Wildhorn Nappe were directly related to the shear deformation of the Helvetic nappes and their emplacement. However, locally the distribution and geometry of folds related to nappe formation is strongly influenced by syn-sedimentary faults that may have played an important role in the localization of major thrusts in the Helvetics and in fold nappe formation, as these surfaces could potentially localize deformation and therefore thrusting. An example is given by an analysis of the profile AB (Fig. 3). Here, the flat portions of the Eaux Froides Fault and the Late Cretaceous Sex-Rouge-Donin and Chamossaire Faults were reused during the Neogene compression, accumulating some $700 \mathrm{~m}$ of displacement. In more important thrusts (e.g. at the base of the Wildhorn Nappe), rotation of the developing overturned limb of a larger-scale fold would bring any pre-existing palaeo-fault into a favourable orientation for reactivation, promoting thrusting rather than folding. As noted by Herwegh and Pfiffner (2005), this would tend to prevent the development of inverted limbs and promote stacking of slices of generally upright stratigraphy. On upright fold limbs, the highangle normal faults were not favourably oriented for reactivation as thrust or reverse faults but rather acted as buttresses, promoting higher amplitude and shorter wavelength folding in the adjacent half-graben basins. Examples of buttressing (Figs. 3, 7b, c, 9a) can be recognized in the hanging wall of the Eaux Froides Fault and of the Sex Rouge-Donin Fault, similar to that described in the French external Alps by Bellahsen et al. (2012). This provides further evidence that these faults existed prior to folding (e.g. Günzler-Seiffert 1942). Although some local reactivation of palaeo-faults did occur during the Alpine orogeny, the steeper parts of the palaeo-faults were commonly passively transported and therefore preserved.

\subsection{Kinematic restoration of Oligocene and Neogene deformation}

The cross section $\mathrm{AB}$ in Fig. 3 is representative of the study area and provides the basis of a kinematic inversion (Fig. 15) to establish both the amount of Cretaceous extension and of Alpine shortening on the generally upright limb of the Wildhorn Nappe. Cross-section AB is based on field data and a subsurface interpretation down to a few kilometres depth, extrapolated from the geometrical relationships at the surface. Unfortunately, no seismic data that could help in the construction of the deeper section are available. The section has been drawn along the mean direction of transport during the Alpine orogenesis, based on the orientation of mesoscopic folds and outcrop-scale structures, such as $\mathrm{S}-\mathrm{C}$ fabrics, slickensides, duplexes, and major and minor reverse faults. The resulting section (Fig. 3) has been manually restored in Fig. 15 by: (1) kinematic inversion of the movement along faults according to the interpreted amount of displacement, and (2) unfolding folds assuming flexural slip. Pin lines were located along zones of (assumed) no inter-bed slip and the back restoration has been performed by using the linelength method. The chosen pin lines are located at the Chamossaire and north of Follhore. The Schrattenkalk Formation is composed of limestones that show little evidence for pervasive internal strain and re-crystallization: this formation is therefore assumed to have preserved the original relationships in length, thickness, and therefore in volume. The sequence of restoration follows the three main stages of deformation, which are, from the youngest to the oldest: (1) transtensive faulting, (2) refolding of the nappe stack, and (3) folding and thrusting related to nappe emplacement. Any significant strike-slip component during either thrusting or later (transtensive) normal faulting 
precludes a strictly quantitative $2 \mathrm{D}$ analysis. Nevertheless, a semi-quantitative approach is attempted in order to produce a first order back-restored model for the upright limb of the Wildhorn Nappe (Figs. 3, 15). Our kinematic restoration gives an amount of shortening (internal to the Wildhorn Nappe) along the section of $\sim 22.5 \%$ $\left(\mathrm{L}_{0}=13.77 \mathrm{~km}\right.$ and $\left.\mathrm{L}_{1}=10.9 \mathrm{~km}\right)$. The restoration also provides an estimate for the amount of extension during the Late Cretaceous of ca. $8.5 \% \quad\left(\mathrm{~L}_{0}=12.6 \mathrm{~km}\right.$ and $\left.\mathrm{L}_{1}=13.77 \mathrm{~km}\right)$.

\subsection{Geodynamic context of Late Cretaceous Helvetic syn-sedimentary faults}

After rifting and opening of the Alpine Tethys (Stampfli 1993), divergence between the European and Apulian plates was accommodated by continental drift and widespread oceanic crust production during the Middle-Late Jurassic in the most internal sectors of the basin (e.g. Liguria-Piemonte domain; Lemoine et al. 1986; Carminati and Doglioni 2004; Bortolotti and Principi 2005; Mohn et al. 2010). From the Early Cretaceous onward, opening of the southern Atlantic Ocean and the lateral migration of Africa towards the north reversed rifting and produced general convergence between Africa and Europe (Phillips and Forsyth 1972; Ziegler 1987; Dewey et al. 1989; Rosenbaum and Lister 2004). Nevertheless, in spite of the onset of drifting in the Middle Jurassic and the generally convergent setting since the Early Cretaceous, the passive margins on both sides of Alpine Tethys experienced repeated extensional events, possibly related to differential rotation of microplates. In fact, an increasing number of studies over the past decades have shown that on-going extension after break-up is an important process affecting the "passive" margins of Alpine Tethys (Manatschal and Bernoulli 1999; Beltrando et al. 2010; Mohn et al. 2010; Vitale Brovarone et al. 2011). Extensional tectonics subsequent to rifting have now been described from different sectors of both the northern and southern Tethyan margins, with significant extensional tectonic activity occurring throughout the Middle and Late Jurassic, the Cretaceous and the Eocene (e.g. Günzler-Seiffert 1942, 1952; Montanari 1988; Marchegiani et al. 1999; Graziano 2000; Casabianca et al. 2002; Santantonio et al. 2013).

In the Gulf of Biscay and in the Valais domain (Stampfli et al. 1998), renewed rifting already started in the MiddleLate Jurassic, driving the Sardo-Corsican and Briançonnais terrains away from the hyperextended European margins (Galster et al. 2012). This event is coeval with the synsedimentary faults described by Günzler-Seiffert (1942, 1952) from the Helvetic domain and with the rifting and drifting that separated Iberia from Newfoundland (Stampfli 1993). The renewed extension affected the already established architecture of the European margin, which was progressively involved in the opening of the Valais domain. In the External Briançonnais domain (Ligurian Alps), Aptian-Cenomanian palaeo-faults with displacements of up to several $100 \mathrm{~m}$ have been interpreted to be related to formation of a pull-apart basin related to the opening of the Valais basin and the rotation of Iberia (Bertok et al. 2012). According to Handy et al. (2010), this is around the time when the Valais ocean started to open and it is therefore reasonable that ongoing extension in the Cretaceous might be related to the progressive opening of the Valais ocean. Continued stretching of the north-western margin during the Late Jurassic-Early Cretaceous may have led to local exhumation of sub-continental mantle and the production of new oceanic crust, although the overall width and importance of the Valais "ocean" remains controversial (Stampfli et al. 1998; Masson et al. 2008; Manatschal and Müntener 2009; Mohn et al. 2010). The more internal Penninic domain was also affected by synsedimentary faulting indicating tectonic activity. Syn-sedimentary normal faulting through the Late Cretaceous was recognized by Hsu (1960) in the Schlieren and Gurnigel Flysch units, although the palaeogeographic position of these units is disputed (South Penninic according to Caron et al. 1989, North Penninic, i.e. Valais domain, according to Trümpy 2006).

Cretaceous syn-sedimentary tectonics have generally been less well-documented and understood in the Helvetic domain. The future Wildhorn Nappe and the more internal Ultrahelvetic nappes were palaeogeographically contiguous and represented the proximal to distal margin of Europe, positioned just north of the Valais domain (Trümpy 1960). This margin was therefore most probably characterized by a major low-angle ramp forming the basal detachment to smaller faultrelated steps of about $400 \mathrm{~m}$ in the hanging wall, each of the steps being similar to the Eaux Froides Fault. The normal faulting developed during late Early-Late Cretaceous in the Helvetic internal domain (i.e. Wildhorn Nappe), as documented in detail in this paper, can most likely be directly related to renewed extension along the European margin. This event further thinned and extended the pre-existing distal European margin developed during the Early-Middle Jurassic. At the end of the Cretaceous, the Helvetic domain, comprising the area of the future Helvetic nappes, was probably ca. $75 \mathrm{~km}$ across (Pfiffner 2011). Along the shortest axis of the basin, which is now approximately perpendicular to the trend of the Swiss Alps, the Ultrahelvetic units were also probably more than $100 \mathrm{~km}$ wide. These sediments rested on a highly-stretched portion of continental crust and were later easily detached from this thin basement during the first "thin-skinned" orogenic phase. 


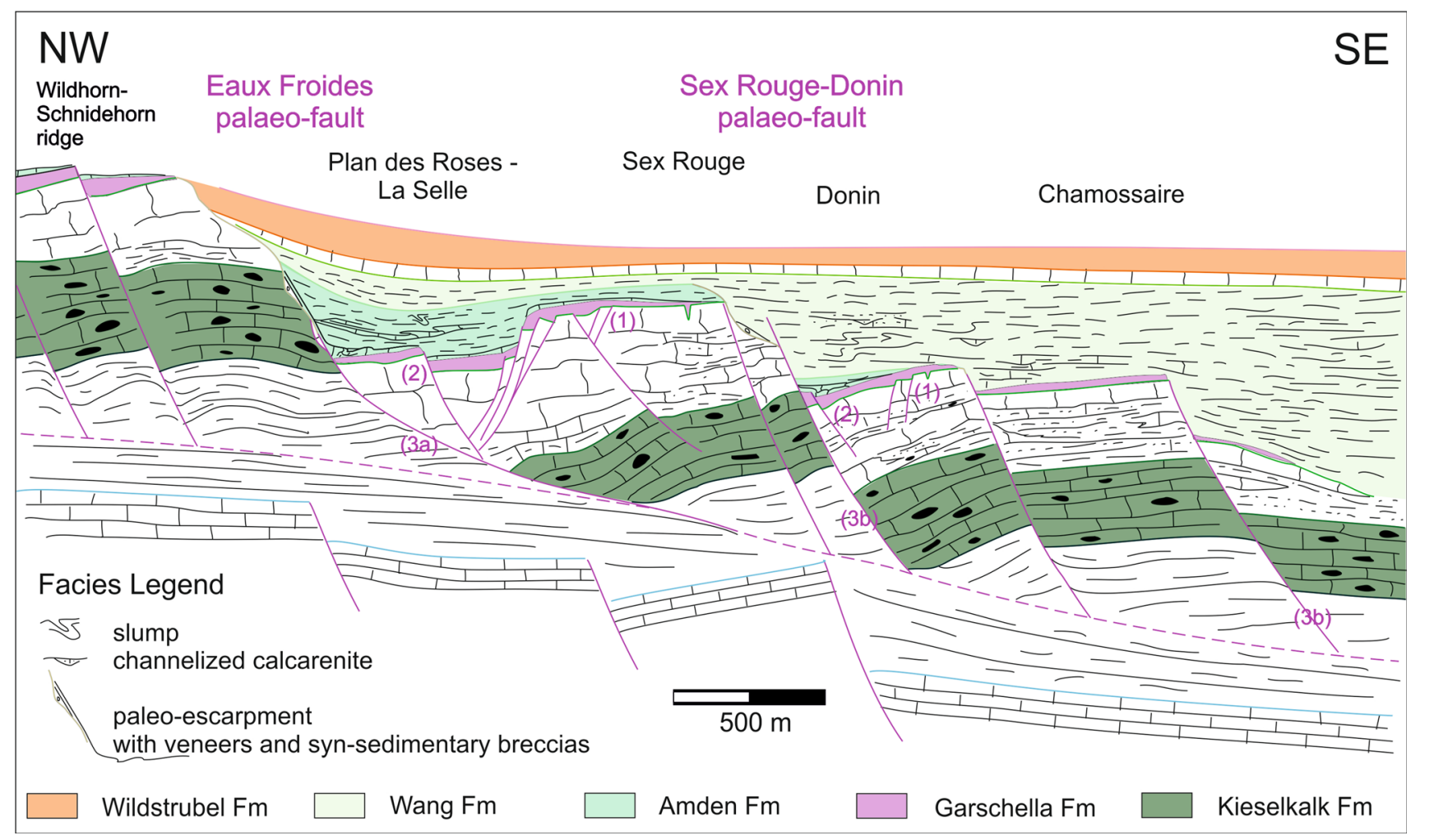

Fig. 14 Cartoon summarizing the sedimentary facies and fault distribution, based on an interpretation of profile $A B$ in Fig. 3. The Schrattenkalk Formation, which is the main scarp-forming unit, lies between Garschella Formation and the Kieselkalk (see Fig. 5). Violet

Late Cretaceous syn-sedimentary faults have been previously recognized on both the northern (European) and southern (Adrian-African) margins of the Mediterranean Tethys (Bernoulli 1964; Bertotti 1991; Santantonio and Carminati 2011). In the sub-Alpine chain of France, which belongs to the northern margin, Michard et al. (2010) interpreted the "ante-Senonian" (Turonian 90 Ma) folding to be related to syn-sedimentary sliding of the Oxfordian-Cenomanian package of semi-consolidated layers onto the "Terres Noires" (Bathonian-Oxfordian shales). This large-scale syn-sedimentary slump folding occurs at the same time as most of the syn-sedimentary faulting documented in the current paper and could belong to the same regional tectonic event. In the Helvetics, Lugeon (1914-1918) and Günzler-Seiffert (1942, 1952) already recognized the occurrence of Cretaceous faults but without going into detail about the exact timing and mode of development. Villars (1989) reported olistoliths of Turonian limestones slumped into the marls of the Amden Formation (Santonian-Campanian) of the Plaine Morte (Wildhorn Nappe) and compared the stratigraphic architecture of the area with similar observations reported by Föllmi (1981) in the Helvetic succession of Vorarlberg (West Austria) and with the pre-Campanian tectonic phase documented by Siddans (1979) and Michard et al. (2010) in numbers in brackets are (1) small-, (2) moderate-, and (3) large-scale faults. Fault set $(3 a)$ was active in the Turonian-Santonian and is mostly represented by the Eaux Froides Fault, whereas $(3 b)$ was active in the Early Maastrichtian (e.g. Sex Rouge-Donin Fault)

the subalpine massif of Dévoluy (French Alps). Föllmi and Gainon (2008) also documented the occurrence of faults and fault breccias affecting the Seewen Formation in the Plaine Morte area. In Helvetic Alps, Stacher (1980) recognized that the unconformity at the top of the Upper Cretaceous succession (i.e. Wang Formation) may have been related to tilt. In addition, Lihou and Allen (1996) related different events of foreland tectonics of the Helvetic and Ultrahelvetic domains to Late Cretaceous-Middle Eocene normal faulting and resedimentation during thrusting and erosion.

In the Late Cretaceous, the future Wildhorn Nappe experienced two pulses of extension in the Turonian-Santonian and in the Early Maastrichtian (Figs. 14, 15). Both these pulses could potentially be related to an early flexure of the Helvetic margin, although it was still several $100 \mathrm{~km}$ away from the orogenic prism. The Liguria-Piemonte oceanic crust started to subduct already in the Early Cretaceous, with subsequent subduction of the continental crust of the Sesia-Lanzo zone during the Late Cretaceous (Froitzheim et al. 1996; Rubatto et al. 2011; Turco et al. 2012 and references therein). Sedimentological evidence from the most distal parts of the Austroalpine thrust wedge indicates that subduction of the Penninic domain (or, more specifically, the Liguria-Piemonte oceanic crust) probably 
Fig. 15 Model for the evolution of faulting in the Cretaceous-Tertiary successions of the Wildhorn Nappe. The back-restoration is based on the geological profile $\mathrm{AB}$ in Fig. 3. Each stage represents the restoration of the main events in the basin evolution
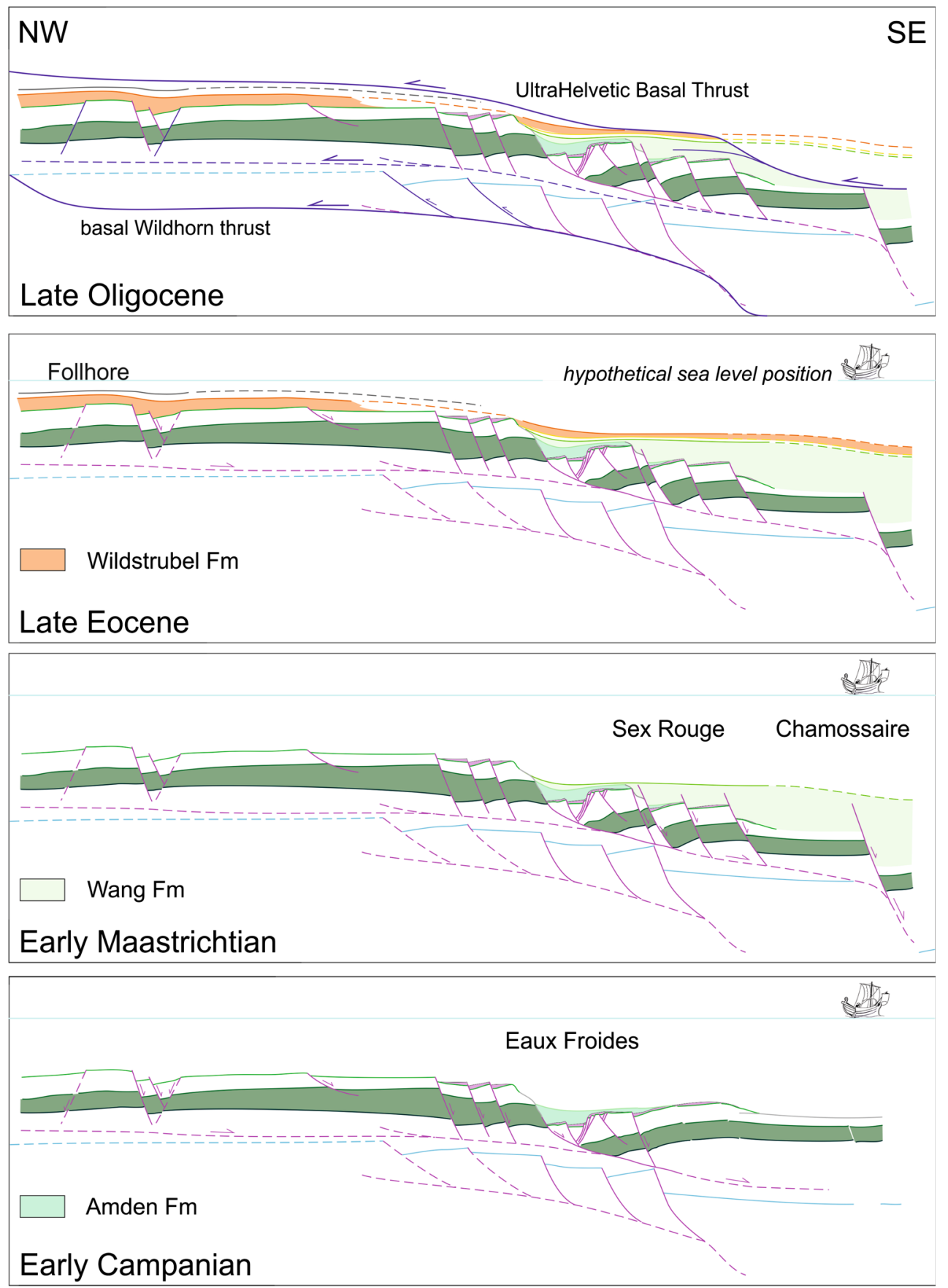

Garschella Fm
$\begin{aligned} & \text { Kieselkalk Fm } \\ & \text { top of Quinten Fm }\end{aligned}$
Late Aptian


started already in the Late Aptian/Albian (Wagreich 2001). If one follows the scenario that the Sesia-Lanzo zone represents a small allochthon of Adriatic continental crust within the Piemont-Ligurian basin (e.g. Elter and Pertusati 1973; Froitzheim and Manatschal 1996; Pleuger et al. 2007), this would be the first continental crust to be subducted. Consistently, the oldest subduction-related metamorphism in eclogitic facies in the Penninic domain is reported from the Sesia-Lanzo zone (75-79 Ma; Rubatto et al. 2011). More external parts of the Penninic palaeogeographic domain were progressively accreted in the Eocene (e.g. Dal Piaz et al. 2001), largely by in-sequence thrusting (e.g. Frisch 1979). The timing of nappe accretion is generally determined by radiometric age dating, usually of peak $\mathrm{P} / \mathrm{T}$ conditions and of retrograde metamorphism during exhumation (see Herwartz et al. 2008 for a compilation of radiometric ages for high-pressure metamorphism in Upper, Middle, Lower, and Subpenninic units). However, the position of the thrust front towards the foreland during such high-grade metamorphic events in internal parts of the orogeny is largely unknown. The same is all the more true for the time before subduction of the Sesia-Lanzo zone (i.e. Rubatto et al. 2011). Indeed, there are currently few constraints on the precise timing of the switch between convergent, quiet, or divergent tectonic regimes in the Alps (Froitzheim et al. 1996; Beltrando et al. 2010).

In terms of a large-scale tectonic reconstruction, we propose four possible scenarios that could generate the observed important syn-sedimentary faulting in the Wildhorn Nappe: (1) extensional foreland tectonics in the more distal domains of the European margin, related to progressive northward propagation of the accretionary prism in the Late Cretaceous. (2) Rift-related extension associated with the final development of the European margin. (3) Extensional collapse of the Cretaceous orogeny, which ended near the Cretaceous-Tertiary boundary, as proposed by Kempf and Pfiffner (2004). (4) Lateral gliding and gravitational collapse of the European margin. Discriminating between these scenarios requires more wide-ranging studies to document the regional extent of the Cretaceous syn-sedimentary tectonics and its structural implications.

\section{Conclusions}

The Wildhorn nappe includes an Upper Cretaceous succession preserving clear evidence for post-breakup extensional tectonics such as: syn-sedimentary geometries related to well oriented NE-striking faults; sedimentary dykes; lateral variations in the thickness and facies of formations; anomalous and discordant contacts corresponding to palaeo-escarpments; and slump folds. Syn-sedimentary faulting took place in three different stages: (1) Post-Cenomanian small-scale and distributed normal faulting; (2) Turonian-Santonian fault localization on larger and more widely spaced growth-fault structures influencing the deposition pattern of re-sedimented deposits; (3) Early Maastrichtian faulting in the southern part of the "alpine region" breaking through the previously formed rollover anticline. Cretaceous syn-sedimentary faults are much more widely developed and of greater magnitude than previously thought, with fault offsets and related changes in sedimentary unit thickness of up to several $100 \mathrm{~m}$. This resulted in a strong pre-structuring of the Helvetic units prior to the Alpine orogeny. However, at least on the upright limbs of the major fold nappes, these high-angle normal faults were not significantly reactivated as reverse faults but rather acted as buttresses, promoting higher amplitude and shorter wavelength folding in the adjacent half-graben basins. The Cretaceous syn-sedimentary fault system runs parallel to the older Jurassic faults and also to the younger Tertiary system reported by previous authors (but unconfirmed in the current study). In the Wildhorn Nappe, Cretaceous faults are well exposed and allow precise timing of the fault displacement, as recorded by the syn-tectonic deposits. Back-restoration shows that the amount of stretch along the total length of the section considered was ca. $8.5 \%$. The studied Cretaceous syn-sedimentary faults cannot be easily related to partial or local gravitational collapse, because the faults crosscut suitable candidates for preferential gliding (e.g. the thick succession of Lower Cretaceous Tierwis Formation shales). In the Wildhorn Nappe, fault activity was largely finished by the Early Maastrichtian rather than continuing into the Tertiary and no clear evidence was found in the study area for any active Tertiary faulting as important as that in the Late Cretaceous. During EoceneOligocene times, mixed siliciclastic and calcareous deposits passively filled the rejuvenated Upper Maastrichtian-Lower Eocene topography and sealed the fault scarps. Widespread post-breakup extension affecting the Mediterranean and Alpine Tethys during the Late Cretaceous may be related to renewed crustal stretching, whereas later Early Tertiary normal faulting documented by other authors in other areas (e.g. in more external nappes) could be associated with preorogenic flexure of the Alpine foreland.

Acknowledgments The authors thank the Swiss National Science Foundation (SNF, Project Number 2-77178-11) for having funded this research. Reviewers Henry Masson, André Strasser and Carlo Bertok are thanked for their thorough and constructive reviews. Helmut Weissert, Massimo Santantonio, Adrian Pfiffner, and Jan Pleuger are kindly thanked for fruitful discussions.

\section{References}

Badoux, H. (1946). L'Ultra-helvétique au Nord du Rhône valaisan. Matériaux pour la Carte Géologique de la Suisse (Nouvelle séries), 85 . 
Badoux, H., Bonnard, E.G., Burri, M., \& Vischer, A. (1959). Feuille 35 St-Leonard et notice explicative. Atlas géologique Suisse 1:25,000. Basel: Commission Géologique Suisse.

Badoux, H., \& Lombard, A. (1962). Feuille 41 Lenk et notice explicative. Atlas géologique Suisse 1:25,000. Bern: Commission Géologique Suisse.

Bayer, A., Bernoulli, D., Breitschmid, A., Funk, H., Gigon, W. O., \& Gygi, R. A. (1983). Bericht uber die Jubilaeumsexkursion, Der Faziesbegriff und die Sedimentationsprozesse"der Schweizerichen Geologischen Gesellschaft vom 12. bis 17. September 1982. Eclogae Geologicae Helvetiae, 76, 125-180.

Bellahsen, N., Jolivet, L., Lacombe, O., Bellanger, M., Boutoux, A., \& Garcia, S. (2012). Mechanisms of margin inversion in the external Western Alps: implications for crustal rheology. Tectonophysics, 576, 20-45.

Beltrando, M., Rubatto, D., \& Manatschal, G. (2010). From passive margins to orogens: the link between ocean-continent transition zones and (ultra)high-pressure metamorphism. Geology, 38, $559-562$.

Bernoulli, D. (1964). Zur Geologie des Monte Generoso. Ein Beitrag zur Kenntnis der südalpinen Sedimente. Beiträge zur Geologischen Karte der Schweiz, Neue Folge 118, 134 pp.

Bertok, C., Martire, L., Perotti, E., d'Atri, A., \& Piana, F. (2012). Kilometer-scale paleoescarpments as evidence for Cretaceous syn-sedimentary tectonics in the External Briançonnais Domain (Ligurian Alps, Italy). Sedimentary Geology, 251-252, 58-75.

Bertotti, G. (1991). Early Mesozoic extension and Alpine shortening in the western Southern Alps: the geology of the area between Lugano and Menaggio (Lombardy, northern Italy). Memorie di Scienze Geologiche, 43.

Bigi, G., \& Carozzo, M.T. (1992). Structural model of Italy and gravity map 1:500,000. Consiglio Nazionale delle Ricerche.

Bortolotti, V., \& Principi, G. (2005). Tethyan ophiolites and Pangea break-up. Island Arc, 14, 442-470.

Bover-Arnal, T., Jaramillo-Vogel, D., Showani, A., \& Strasser, A. (2011). Late Eocene transgressive sedimentation in the western Swiss Alps: records of autochthonous and quasi-autochthonous biofacies on a karstic rocky shore. Palaeogeography, Palaeoclimatology, Palaeoecology, 312, 24-39.

Burkhard, M. (1988). L'Helvétique de la bordure occidentale du massif de l'Aar (évolution tectonique et métamorfique). Eclogae Geologicae Helvetiae, 81, 63-114.

Burkhard, M., \& Kerrich, R. (1988). Fluid regimes in the deformation of the Helvetic nappes, Switzerland, as inferred from stable isotope data. Contributions to Mineralogy and Petrology, 99, 416-429.

Bussy, F., \& Epard, J.-L. (1984). Essai de zonéographie métamorphique entre les Diablerets et le massif de l'Aar (Suisse occidentale), basée sur l'étude des Grès de Taveyanne. Schweizerische Mineralogische und Petrographische Mitteilungen, 64, 131-150.

Cardello, G.L. (2013). The Rawil depression: its structural history from Cretaceous to Neogene. Ph.D. dissertation, Switzerland: ETH Zürich. doi:10.3929/ethz-a-010016215.

Cardello, G. L., \& Tesei, T. (2013). Transtensive faulting in carbonates at different crustal levels: examples from SW Helvetics and Central Apennines. Rendiconti online della Società Geologica Italiana, 29, 20-23.

Carminati, E., \& Doglioni, C. (2004). Mediterranean geodynamics. Encyclopedia of Geology, 135-146. Elsevier.

Caron, C., Homewood, P., \& Wildi, W. (1989). The original Swiss flysch: a reappraisal of the type deposits in the Swiss Prealps. Earth-Science Reviews, 26, 1-45.

Casabianca, D., Bosence, D., \& Beckett, D. (2002). Reservoir potential of Cretaceous platform-margin breccias, Central Italian Apennines. Journal of Petroleum Geology, 25, 179-202.
Dal Piaz, G., Cortiana, G., Del Moro, A., Martin, S., Pennacchioni, G., \& Tartarotti, P. (2001). Tertiary age and paleostructural inferences of the eclogitic imprint in the Austroalpine outliers and Zermatt-Saas ophiolite, western Alps. International Journal of Earth Sciences, 90, 668-684.

Dewey, J. F., Helman, M. L., Turco, E., Hutton, D. H. W. \& Knott, S. D. (1989). Kinematics of the western Mediterranean. In M. P. Coward, D. Dietrich, R. G. Park (Eds.), Alpine tectonics (vol. 45, pp. 265-283). Geological Society of London Special Publications.

Elter, P., \& Pertusati, P. (1973). Considerazioni sul limite AlpiAppennino e sulle relazioni con l'arco delle Alpi occidentali. Memorie della Società Geologica Italiana, 12, 359-375.

Escher, A., Masson, H., \& Steck, A. (1993). Nappe geometry in the Western Swiss Alps. Journal of Structural Geology, 15, 501-509.

Föllmi，K. B. (1981). Sedimentäre Hinweise auf oberkretazische Tektonik im Vorarlberger Helvetikum. Eclogae geologicae Helvetiae, 74/1, 175-187.

Föllmi, K. B., \& Gainon, F. (2008). Demise of the northern Tethyan Urgonian carbonate platform and subsequent transition towards pelagic conditions: the sedimentary record of the Col de la Plaine Morte area, central Switzerland. Sedimentary Geology, 205, $142-159$.

Föllmi, K. B., Bodin, S., Godet, A., Linder, P., \& Van De Schootbrugge, B. (2007). Unlocking paleo-environmental information from Early Cretaceous shelf sediments in the Helvetic Alps: stratigraphy is the key!. Swiss Journal of Geosciences, 100, 349-369.

Frisch, W. (1979). Tectonic progradation and plate tectonic evolution of the Alps. Tectonophysics, 60, 121-139.

Froitzheim, N., \& Manatschal, G. (1996). Kinematics of Jurassic rifting, mantle exhumation, and passive-margin formation in the Austroalpine and Penninic nappes (eastern Switzerland). Geological Society of America Bulletin, 108, 1120-1133.

Froitzheim, N., Schmid, S., \& Frey, M. (1996). Mesozoic paleogeography and the timing of eclogite facies metamorphism in the Alps: a working hypothesis. Eclogae Geologicae Helvetiae, 89, 81-110.

Galster, F., Cavargna-Sani, M., Epard, J. L., \& Masson, H. (2012). New stratigraphic data from the Lower Penninic between the Adula nappe and the Gotthard massif and consequences for the tectonics and the paleogeography of the Central Alps. Tectonophysics, 579, 37-55.

Gasser, D., \& Mancktelow, N. S. (2010). Brittle faulting in the Rawil depression: field observations from the Rezli fault zones, Helvetic nappes, western Switzerland. Swiss Journal of Geosciences, 103, 15-32.

Graziano, R. (2000). The Aptian-Albian of the Apulia Carbonate Platform (Gargano Promontory, southern Italy): evidence of paleogeographic and tectonic controls on the stratigraphic architecture of the platform margin. Cretaceous Research, 21, $107-126$.

Günzler-Seiffert, H. (1932). Gefaltete Brüche im Jura des Kientals. Eclogae Geologicae Helvetiae, 25, 237-238.

Günzler-Seiffert, H. (1934). Lauterbrunnen und nördl. Randgebiet von Blatt 488 Blümlisalp. Geologischer Atlas der Schweiz, Erläuterungen, 6, 12.

Günzler-Seiffert, H. (1942). Persistente Brücke im Jura der WildhornDecke des Berner Oberlandes. Eclogae Geologicae Helvetia, 34 , 164-172.

Günzler-Seiffert, H. (1952). Alte Brücke im Kreide/Tertiär-Anteil der Wildhorndecke zwischen Rhone und Rhein. Geologisches Rundshau, 40, 211.

Haile, N. S. (1987). Time and age in geology: the use of Upper/ Lower, late/early in stratigraphic nomenclature. Marine and Petroleum Geology, 4, 255-257. 
Handy, M. R., Schmid, M.S., Bousquet, R., Kissling, E., \& Bernoulli, D. (2010). Reconciling plate-tectonic reconstructions of Alpine Tethys with the geological-geophysical record of spreading and subduction in the Alps. Earth-Science Reviews, 102, 121-158.

Heim, A. (1920). Geologie der Schweiz. Leipzig: B. Tauchnitz Verlag Gmbh.

Herb, R. (1988). Eocaene Palaeogeographie und Palaeotektonik des Helvetikums. Eclogae Geologicae Helvetiae, 81, 611-657.

Herwartz, D., Münker, C., Scherer, E. E., Nagel, T. J., Pleuger, J., \& Froitzheim, N. (2008). Lu-Hf garnet geochronology of eclogites from the Balma Unit (Pennine Alps): implications for Alpine plate tectonic reconstructions. Swiss Journal of Geosciences, 101(Supplement 1), S173-S189. doi:10.1007/s00015-008-1292-y.

Herwegh, M., \& Pfiffner, O. A. (2005). Tectono-metamorphic evolution of a nappe stack: a case study of the Swiss Alps. Tectonophysics, 404, 55-76.

Hsu, K. J. (1960). Paleocurrent structures and paleogeography of the Ultrahelvetic flysch basins, Switzerland. Geological Society of America Bulletin, 71, 577-610.

Huggenberger, P., \& Aebli, H. (1989). Bruchtektonik und Blattverschiebungen im Gebiet des Rawil-Passes; Resultat einer E-W gerichteten dextralen Schwerbewegung im kristallinen Untergrund? Schweizerische Mineralogische und Petrographische Mitteilungen, 69, 173-180.

Kastrup, U., Zoback, M. L., Deichmann, N., Evans, K. F., Giardini, D., \& Michael, A. J. (2004). Stress field variations in the Swiss Alps and the northern Alpine foreland derived from inversion of fault plane solutions. Journal of Geophysical Research, 109, B01402. doi:10.1029/2003JB002550.

Kempf, O., \& Pfiffner, O. A. (2004). Early Tertiary evolution of the North Alpine Foreland Basin of the Swiss Alps and adjoining areas. Basin Research, 16, 549-567.

Kirschner, D. L., Masson, H., \& Cosca, M. A. (2003). An ${ }^{40} \mathrm{Ar} /{ }^{39} \mathrm{Ar}$, $\mathrm{Rb} / \mathrm{Sr}$, and stable isotope study of micas in low-grade fold-andthrust belt: an example from the Swiss Helvetic Alps. Contributions to Mineralogy and Petrology, 145, 460-480.

Lemoine, M., Bas, T., Arnaud-Vanneau, A., Arnaud, H., Dumont, T., \& Gidon, M. (1986). The continental margin of the Mesozoic Tethys in the Western Alps. Marine and Petroleum Geology, 3, 179-199.

Lihou, J. C., \& Allen, P. A. (1996). Importance of inherited rift margin structures in the early North Alpine Foreland Basin, Switzerland. Basin Research, 8, 425-442.

Lugeon, M. (1914-1918). Les Hautes Alpes calcaires entre la Lizerne et la Kander: (Wildhorn, Wildstrubel, Balmhorn et Torrenthorn): (explication de la carte spéciale no. 60). 3 Fascicule. Matériaux pour la carte géologique de la Suisse. Nouvelle série 60.

Manatschal, G., \& Bernoulli, D. (1999). Rifting and early evolution of ancient ocean basins: the record of the Mesozoic Tethys and of the Galicia-Newfoundland margins. Marine Geophysical Researches, 20, 371-381.

Manatschal, G., \& Müntener, O. (2009). A type sequence across an ancient magma-poor ocean-continent transition: the example of the western Alpine Tethys ophiolites. Tectonophysics, 473, 4-19.

Marchegiani, L., Bertotti, G., Cello, G., Deiana, G., Mazzoli, S., \& Tondi, E. (1999). Pre-orogenic tectonics in the Umbria-Marche sector of the Afro-Adriatic continental margin. Tectonophysics, $315,123-143$

Masson, H., Bussy, F., Eichenberger, M., Giroud, N., Meilhac, C., \& Presniakov, S. (2008). Early Carboniferous age of the Versoyen ophiolites and consequences: non-existence of a "Valais ocean" (Lower Penninic, western Alps). Bulletin de la Société géologique de France, 179, 337-355.

Maurer, H. R., Burkhard, M., Deichmann, N., \& Green, A. G. (1997). Active tectonism in the central Alps: contrasting stress regimes north and south of the Rhone Valley. Terra Nova, 9, 91-94.
Menkveld-Gfeller, U. (1995). Stratigraphie, Fazies und Palaeogeographie des Eocaens der helvetischen Decken der Westschweiz (Diablerets- und Wildhorn-Decke). Eclogae Geologicae Helvetiae, 88, 115-134.

Michard, A., Dumont, T., Andreani, L., \& Loget, N. (2010). Cretaceous folding in the Dévoluy Mountains (Subalpine Chains, France): gravity driven detachment at the European paleomargin versus compressional event. Bulletin de la Société Géologique de France, 6, 565-581.

Mohn, G., Manatschal, G., Müntener, O., Beltrando, M., \& Masini, E. (2010). Unravelling the interaction between tectonic and sedimentary processes during lithospheric thinning in the Alpine Tethys margins. International Journal of Earth Sciences, 99(Supplement 1), 75-101.

Montanari, A. (1988). Tectonic implications of hydrothermal mineralization in the Late Cretaceous-Early Tertiary pelagic basin of the Northern Apennines. Bollettino della Società Geologica Italiana, 107, 399-411.

Owen, D. E. (2009). How to use stratigraphic terminology in papers, illustrations, and talks. Stratigraphy, 6, 106-116.

Pavoni, N. (1980). Comparison of focal mechanisms of earthquakes and faulting in the Helvetic zone of the Central Valais, Swiss Alps. Eclogae Geologicae Helvetiae, 73, 551-558.

Pfiffner, A. O. (1993). The structure of the Helvetic nappes and its relation to the mechanical stratigraphy. Journal of Structural Geology, 15, 511-521.

Pfiffner, A. O. (2009). Geologie der Alpen. Bern: Haupt Verlag.

Pfiffner, A. O. (2011). Structural map of the Helvetic zone of the Swiss Alps including Vorarlberg (Austria) and Haute Savoie (France) 1:100,000. Federal Office of Topography SwissTopo.

Phillips, J. D., \& Forsyth, D. (1972). Plate tectonics, paleomagnetism, and the opening of the Atlantic. Geological Society of America Bulletin, 83, 1579-1600.

Pleuger, J., Roller, S., Walter, J. M., Jansen, E., \& Froitzheim, N. (2007). Structural evolution of the contact between two Penninic nappes (Zermatt-Saas zone and Combin zone, Western Alps) and implications for the exhumation mechanism and palaeogeography. International Journal of Earth Sciences, 96, 229-252.

Ramsay, J. G. (1989). Fold and fault geometry in the western Helvetic nappes of Switzerland and France and its implication for the evolution of the arc of the Western Alps. In M. P. Coward, D. Dietrich, R. G. Park (Eds.), Alpine tectonics (vol. 45, pp. 33-45). Geological Society of London Special Publications.

Ramsay, J. G., Casey, M., Dietrich, D., Kligfield, R., Mancktelow, N., Schmid, S., Siddans, A. W. B., \& Pfiffner, A. O. (1981). Strain features of the Helvetic nappes of Switzerland. In The Geological Society of America, 94th annual meeting 13. Abstracts with Programs-Geological Society of America, 535.

Ramsay, J. G., Casey, M., \& Kligfield, R. (1983). Role of shear in development of the Helvetic fold-thrust belt of Switzerland. Geology, 11, 439-442.

Rankey, E. C., \& Doolittle, D. F. (2012). Geomorphology of carbonate platform-marginal uppermost slopes: insights from a Holocene analogue, Little Bahama Bank, Bahamas. Sedimentology, 59, 2146-2171.

Rosenbaum, G., \& Lister, G. (2004). Formation of arcuate orogenic belts in the western Mediterranean region. Special Paper Geological Society of America, 8, 107-130.

Rubatto, D., Regis, D., Hermann, J., Boston, K., Engi, M., \& Beltrando, M. (2011). Yo-yo subduction recorded by accessory minerals in the Italian Western Alps. Nature Geoscience, 4, $338-342$.

Santantonio, M., \& Carminati, E. (2011). Jurassic rifting evolution of the Apennines and Southern Alps (Italy): parallels and differences. Geological Society of America Bulletin, 123, 468-484. 
Santantonio, M., Galluzzo, F., \& Gill, G. (1996). Anatomy and palaeobathymetry of a Jurassic pelagic carbonate platform/basin system. Rossa Mts, Central Apennines (Italy). Geological implications. Palaeopelagos, 6, 123-169.

Santantonio, M., Scrocca, D., \& Lipparini, L. (2013). The OmbrinaRospo Plateau (Apulian Platform): evolution of a carbonate platform and its margins through the Jurassic and Cretaceous. Marine and Petroleum Geology, 42, 4-29.

Siddans, A. W. B. (1979). Arcuate fold and thrust pattern in the Subalpine Chains of southeast France. Journal of Structural Geology, 1, 117-126.

Stacher, P. (1980). Stratigraphie, Mikrofazies und Mikropaläontologie der Wang-Formation (Helvetische Oberkreide der Schweizer Alpen). Bern: Stämpfli. 98 pp.

Stampfli, G. M. (1993). Le Briançonnais, terrain exotique dans les Alpes? Eclogae Geologicae Helvetiae, 86, 1-45.

Stampfli, G. M., Mosar, J., Marquer, D., Marchant, R., Baudin, T., \& Borel, G. (1998). Subduction and obduction processes in the Swiss Alps. Tectonophysics, 296, 159-204.

Strasser, A. (1982). Fazielle und sedimentologische Entwicklung des Betlis-Kalkes (Valanginian) im Helvetikum der Zentral- und Ostschweiz. Eclogae Geologicae Helvetiae, 75, 1-21.

Trümpy, R. (1960). Paleotectonic evolution of the central and western Alps. Geological Society of America Bulletin, 71, 843-908.

Trümpy, R. (1980). Geology of Switzerland: a guide book. Basel: Wepf and Company. 334 pp.

Trümpy, R. (2006). Geologie der Iberger Klippen und ihrer FlyschUnterlage. Eclogae Geologicae Helvetiae, 99, 79-121.

Turco, E., Macchiavelli, C., Mazzoli, S., Schettino, A., \& Pierantoni, P. P. (2012). Kinematic evolution of Alpine Corsica in the framework of Mediterranean mountain belts. Tectonophysics, 579, 193-206.

Ustaszweski, M., \& Piffner, A. (2008). Composite faults in the Swiss Alps formed by the interplay of tectonics, gravitation and postglacial rebound: an integrated field and modelling study. Swiss Journal of Geosciences, 101, 223-235.

Villars, F. (1989). Mégablocs resédimentés dans les Marnes d'Amden de la Plaine Morte (nappe helvétique du Wildhorn, Suisse): tectonique synsédimentaire à la fin du Santonien. Schweizer Mineralogische und Petrographische Mitteilungen, 69, 167-172.

Vitale Brovarone, A., Beltrando, M., Malavieille, J., Giuntoli, F., Tondella, E., Groppo, C., Beyssac, O., \& Compagnoni, R. (2011). Inherited ocean-continent transition zones in deeply subducted terranes: insights from Alpine Corsica. Lithos, 124, 273-290.

Wagreich, M. (2001). A 400-km-long piggyback basin (Upper Aptian-Lower Cenomanian) in the Eastern Alps. Terra Nova, $13,401-406$.

Wieland, B. (1976). Petrographie Eozäner Siderolithischer Gesteine des Helvetikums der Schweiz. PhD thesis, University of Bern, $117 \mathrm{pp}$.

Zalasiewicz, J., Cita, M. B., Hilgen, F., Pratt, B. R., Strasser, A., \& Thierry, J. (2013). Chronostratigraphy and geochronology: a proposed realignment. GSA Today, 23, 4-8.

Ziegler, (1987). Late Cretaceous and Cenozoic intra-plate compressional deformations in the Alpine foreland-a geodynamic model. Tectonophysics, 137, 389-420. 